\title{
KNOWLEDGE SPILLOVERS AND OUTPUT PER WORKER: AN INDUSTRY-LEVEL ANALYSIS FOR OECD COUNTRIES
}

\author{
IOANNIS BOURNAKIS, DIMITRIS CHRISTOPOULOS and SUSHANTA MALLICK*
}

\begin{abstract}
This study analyzes the impact of knowledge spillovers on output per worker at the industry level using a primal production function approach. The article makes three different contributions to the international spillovers literature: (1) it identifies traderelated spillovers under alternative assumptions regarding the information transferred through imports; (2) it explores the importance of horizontal and vertical foreign direct investment (FDI) in knowledge spillovers; and (3) it looks at how institutional factors determine the impact of FDI-related spillovers on productivity. The main findings of the study are: (1) international knowledge spillover is an important driver of industry output per worker, and the magnitude of this spillover effect varies with alternative assumptions about the information content embodied in imports, while high technology industries benefit significantly more from import-related knowledge spillovers; and (2) the gains from FDI spillovers are primarily horizontal, but when institutional factors are considered, countries with stronger protection of intellectual property rights and a high "ease of doing business" tend to experience a substantial increase in the effectiveness of both horizontal and vertical FDI-related spillovers. (JEL E24, F1, F6, O3, O4)
\end{abstract}

\section{INTRODUCTION}

Improving the level of productivity is widely regarded as the main source of welfare and economic prosperity. Over the last 50 years, economic literature has identified various drivers of productivity in an attempt to understand the sources of persistent productivity differentials across countries. Historically, developed nations followed a strategy of physical and human capital deepening in stimulating growth and higher levels of per capita income (Dougherty and Jorgenson 1996; Klump, McAdam, and Willman 2008; Van Ark et al. 1993). As countries approach the international technological frontier, to remain in

${ }^{*}$ We are grateful to the participants of the 16th Annual ETSG Conference in LMU Munich, and the 7th FIW Conference in Vienna. Special thanks are due to Professor Elhanan Helpman, Peter McAdam, Dimitra Petropoulou, Daryna Grechyna, Daniel Goya, and Mark Houssart for their suggestions. The usual disclaimer applies.

Bournakis: Senior Lecturer, Department of Economics, Middlesex University, London, NW4 4BT, UK. Phone (44) 208411 5349, E-mail I.Bournakis@mdx.ac.uk

Christopoulos: Professor, Department of Economic and Regional Development, Panteion University, Athens, 176 71, Greece. Phone (30) 210-9201863, E-mail christod@panteion.gr

Mallick: Professor, School of Business and Management, Queen Mary University of London, London, E1 4NS, UK. Phone (44) 207882 7447, Fax (44) 207882 3615, E-mail s.k.mallick@qmul.ac.uk a high growth trajectory they must invest in the generation of new knowledge and ideas through Research and Development (R\&D). ${ }^{1}$

In parallel with the investigation of channels that create new knowledge, the research

1. See Romer (1986) and Aghion and Howitt (1998) for some of the most original developments in the theory of endogenous growth. See also Corrado and Hulten (2010) for a recent overview of this literature.

\section{ABBREVIATIONS}

AB: Arellano and Bond

CCEMG: Common Correlated Effects Mean Group Estimator

CD: Cross-Sectional Dependence

CRS: Constant Returns to Scale

FDI: Foreign Direct Investment

GFCK: Gross Fixed Capital Stock

GMM: Generalized Method of Moments

HFDI: Horizontal Foreign Direct Investment

ISP: International Spillover Index

OECD: Organisation for Economic Co-operation and Development

POLS: Pooled Ordinary Least Squares

R\&D: Research and Development

RDS: R\&D Spending

SUR: Seemingly Unrelated Regression

TFP: Total Factor Productivity

VFDI: Vertical Foreign Direct Investment 
agenda has focused on the importance of knowledge diffusion (Syverson 2011) as an equally crucial driver of productivity. Grossman and Helpman (1991), Keller (1998, 2004, 2010), León-Ledesma (2005), and Ang and Madsen (2013) consider international trade as a conduit for the diffusion of foreign knowledge, which in turn improves productivity performance. Trade and particularly imports increase contacts with foreign producers which enhance knowledge spillovers.

$R \& D$ also generates gains via higher social returns to innovation; the importance of the social returns to $\mathrm{R} \& \mathrm{D}$ always depends on the effective transmission of existing knowledge. Knowledge spillovers can be either national or international in scope, with laggard countries assuming special significance (Mancusi 2008) as they provide access to technological expertise and advanced know-how without incurring the cost associated with research fertility. Although the existence of knowledge spillovers is acknowledged in the production process, to quantify their contribution to output is not straightforward (Hall, Mairesse, and Mohnen 2010). To start with, research appropriability is not always granted and because knowledge is a nonexcludable good it can easily spill over to agents that do not bear the cost of innovation input. In this case, the social rate of $R \& D$ return ${ }^{2}$ is usually bigger than initially expected even if it is not accurately measured (Meijl 1997). A common thread in the literature is that imports and foreign direct investment (FDI) are the main channels of international knowledge transmission but an effective measure of international knowledge transfer encounters substantial frictions (Keller 2010; Van Pottelsberghe and Lichtenberg 2001). First, knowledge spillovers are basically externalities ${ }^{3}$ which are not easily codifiable, as the amount of information embodied is tacit in nature. Therefore, the diffusion of knowledge through imports and FDI is not an automatic process. Second, a key objective derived from the previous consideration is how to construct appropriate pools of international knowledge spillovers. This issue remains highly controversial and puzzling (Coe, Helpman, and Hoffmaister 2009;

2. The latter effect is of special interest to policy makers that design polices associated with R\&D subsidies and R\&Drelated tax exemptions.

3. Knowledge diffusion might also happen via transactions such as royalties, licences, and copyrights. In this case, the existence of actual data can make it easier for the measure of technology transfer.
Falvey, Foster, and Greenaway 2004; Funk 2001; Keller 1998), casting serious doubt about the real economic impact of knowledge spillovers on productivity. To contribute to this agenda the present study relaxes the assumption (Coe and Helpman 1995; Coe, Helpman, and Hoffmaister 1997; Engelbrecht 1997) that a unit of imports always contains the full amount of knowledge used to produce it; instead we assume that the scale of information transferred from the source to destination country varies; thus alternative weighting schemes need to be used to measure knowledge spillovers. We use industry level data, which is rather limited in the current spillovers literature for 12 manufacturing industries in 14 Organisation for Economic Co-operation and Development (OECD) countries. The few but important industry level studies (Acharya and Keller 2009; Bernstein and Yan 1997; Park 2004; Schiff and Wang 2006) do not address the controversial issue of measuring alternative pools of international spillovers but rely on a universal index of knowledge spillovers assuming that a unit of trade provides full information about the knowledge required to produce it.

The present study also incorporates an institutional dimension. The existence of an appropriate institutional environment is potentially a crucial productivity driver as it determines how efficiently foreign knowledge is utilized in the domestic production. Earlier studies (Coe and Helpman 1995; Kao, Chiang, and Chen 1999; Keller 1998) as well as a more recent one (Ang and Madsen 2013) focus on various transmission channels of knowledge spillovers while they neglect the institutional status in the recipient country. Coe, Helpman, and Hoffmaister (2009), using country data, show that the potential of knowledge transfer depends on the degree of patent protection in the host country. The persistent cross-country as well as cross-industry productivity differentials imply that the evolution of the spillover-led productivity process is not always straightforward and there are still many unexplored components in this puzzle. One of these components is how the institutional framework in the recipient country interacts with the traditional transmission channels. In particular, the present study looks at the ease of doing business and protection of intellectual property rights as conditions for the effective absorption of FDI-related spillovers.

The study encompasses industry level data to overcome the standard bias of highly aggregate data (Hall, Mairesse, and Mohnen 2010). We do 
not assume country homogeneity but allow for industries to have different capabilities in absorbing spillovers. In a similar line of argument, we explore the possibility that spillovers can also be intranational as imitation of knowledge can also occur across industries within a country.

Methodologically, we use a primal approach following Griliches (1979) in specifying a production function whose technological parameter is modeled as function of human capital, domestic knowledge, and international R\&D spillovers. The two channels of knowledge spillovers considered are imports (Ang and Madsen 2013; Yasar 2013) and FDI (Branstetter 2006; Carr, Markusen, and Maskus 2001; Havranek and Irsova 2011), recognizing that international exchange of goods and factors embodies substantial information about foreign $R \& D$ stock. We construct four indices of international spillovers that allow for different weighting schemes depending on the scale of information embodied in the standard transmission channel of imports. We also test whether the effect of FDI-related spillovers increases if the host country offers a business friendly environment with strong protection of intellectual property rights.

The remainder of this article is organized as follows: Section II presents the analytical framework; Section III shows the measurement of knowledge spillovers; Section IV discusses the data with econometric specifications; Section $\mathrm{V}$ presents results from import and FDI-related spillovers, including results from the institutional aspect of spillovers; and Section VI concludes.

\section{THEORETICAL FRAMEWORK}

\section{A. The Production Function: The Benchmark Model}

We assume a standard industry-level production function of the form:

$$
Q_{i c t}=A_{i c t}(L)_{i c t}^{\alpha_{1}}(K)_{i c t}^{\alpha_{2}}(M)_{i c t}^{\alpha_{3}},
$$

where $A, L, K$, and $M$ stand for Hicks neutral technical progress, labor, fixed capital, and intermediate materials. Parameters $\alpha_{1}, \alpha_{2}$, and $\alpha_{3}$ are to be estimated and represent shares of labor, fixed capital, and intermediate materials to output. ${ }^{4}$ Subscript $i=1, \ldots, I$ indexes industry, subscript $c=1, \ldots, C$ refers to country, and

4. See Klump, McAdam, and Willman (2012) for a useful guide regarding methods that can be used to overcome empirical uncertainties in estimating these functions. subscript $t=0, \ldots, T$ denotes time. Expressing both sides of Equation (1) in per worker units and taking logs (letters in lower cases) we get:

$$
q_{i c t}=a_{i c t}+\alpha_{2} k_{i c t}+\alpha_{3} m_{i c t} .
$$

Total factor productivity (TFP) $a_{i, c, t}$ is then modeled as:

(3)

$$
\begin{aligned}
& a_{i c t} \equiv \operatorname{lnTFP}{ }_{i c t}=\lambda_{i}+\eta_{c}+\beta \ln h_{i c t}+\gamma \ln r_{i c t} \\
& +\varphi \operatorname{lnDSP} \operatorname{sict}_{i}+\theta \operatorname{lnISP}_{i c t}+u_{i c t} \text {. }
\end{aligned}
$$

Equation (3) states that TFP in industry $i$, in country $c$, at year $t$ depends on human capital, ${ }^{5}$ industry $i$ 's R\&D stock per worker $r_{i c t}$, domestic knowledge spillovers ( $\left.\mathrm{DSP}_{i c t}\right)$, and international knowledge spillovers (ISP $i f t$ ). Parameters $\varphi$ and $\theta$ capture the responsiveness of TFP with respect to domestic and foreign spillovers, respectively. We use our different indices of international spillovers, with each of them depending on a different weighting scheme. ${ }^{6}$ Parameters $\lambda_{i}$ and $\eta_{c}$ capture unobserved industry and country specific idiosyncrasies that drive productivity. Finally, Equation (3) is augmented with a stochastic error term with zero mean and constant variance, $u: \operatorname{IID}\left(0, \sigma^{2}\right)$. The current framework adopts most of the key features of the primal approach (Good, Nadiri, and Sickles 1996; McAdam and Willman 2013; Ortega-Argilés, Vivarelli, and Voigt 2009; Rogers 2010) ${ }^{7}$ in estimating output but industry $i$ 's knowledge stock and associated knowledge spillovers are determinants of TFP instead of direct inputs in the production function. ${ }^{8}$ Merging Equation (2) with Equation (3) yields:

$$
\begin{aligned}
& q_{i c t}=\lambda_{i}+\eta_{c}+\alpha_{2} k_{i c t}+\alpha_{3} m_{i c t}+\beta \ln h_{i c t} \\
& \quad+\gamma \ln r_{i c t}+\varphi \operatorname{lnDSP} \operatorname{lict}_{i c t}+\theta \operatorname{lnISP}_{i c t}+u_{i c t} .
\end{aligned}
$$

5. We follow a long tradition in the literature of growth empirics (Benhabib and Spiegel 1994; Islam 1995) by including human capital in the TFP equation instead of an input in the production function.

6. The weighting scheme implies that there are different interpretations of the amount of information transferred and received between sender and recipient country. Section III describes the four alternative weighting schemes used in this study.

7. See also Griliches (1979), Griliches (1980), and Griliches and Mairesse (1984) for earlier studies using the production function approach.

8. Eberhardt, Helmers, and Strauss (2013) use a different approach without using specific international knowledge spillovers, focusing instead on the establishment of an econometric correlation between output and unobserved factors which are attributed to spillovers. Their estimation technique is a variation of the Pesaran (2006) estimator used in this paper, see Section IV. 
To sum up, the parameters to be estimated - in this extended production function-are of: traditional production inputs $\left(\alpha_{2}\right)$ and $\left(\alpha_{3}\right)$, human capital $(\beta)$, industry's own R\&D stock $(\gamma)$, domestic spillovers $(\varphi)$, and international spillovers $(\theta)$. Note parameter $\theta$ will be estimated separately for each different pool of knowledge spillovers.

\section{MEASUREMENT OF KNOWLEDGE SPILLOVERS}

$R \& D$ does not always lead to new inventions, and thus research outcomes are not normally protected, which permits us to further explore hypotheses associated with the amount of information transferred through imports. A set of four international spillovers indices is defined to capture whether different proportions of knowledge are transferred in the domestic industry based on whether knowledge is regarded as a pure public or private good.

We first start with domestic spillovers from $R \& D$ stock ${ }^{9}$ across industries in the same country. This index assumes that the flow of inter-industry R\&D spillovers is parallel to the flow of commodities. The size of domestic R\&D spillovers (DSP) is analogous to the degree of "technological proximity" (Branstetter 2001) between industries $i$ and $j .{ }^{10}$ The index of DSP is defined as follows:

$$
\mathrm{DSP}_{i c t}=\sum_{i \neq j} \omega_{i j c} R_{j c t},
$$

where $\omega$ is an element of the Leontief inverse matrix. The inverse matrix is generated from an input-output table that describes sales and purchases of commodities between industry $i$ and $j$ within country $c .^{11}$

To address the various controversies related to the measurement of international knowledge spillovers, we construct a set of indices using

9. $\mathrm{R} \& \mathrm{D}$ stock is computed as follows: $R_{i t}=(1-$

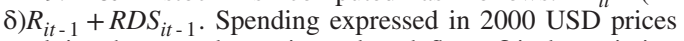
applying the gross domestic product deflator, $\delta$ is depreciation rate of $R \& D$ stock taken as common for all industries at $15 \%$ (Hall, Mairesse, and Mohnen 2010). The R\&D stock series is initiated from a steady state formula identical to the one derived for physical capital: $\Delta R_{i t}=0 \Rightarrow R D S_{i t} \approx\left(g_{i}+\delta\right) R_{i,-1}$ or for the initial period $R_{i t=0}=R D S_{i t=0} / g_{i}+\delta$.

10 . $R \& D$ activity in industries of intermediate inputs supplier facilitates gains for downstream industries. The stronger is the degree of engagement between these two types of industries, the greater is the potential of R\&D spillover.

11. We prefer this weighting for domestic spillovers instead of averaging R\&D stock in country $c$. Industrial linkages have been found to be of particular importance for technical progress and productivity (Wolff and Nadiri 1993). different assumptions for the amount of knowledge transferred and received through imports (Falvey, Foster, and Greenaway 2004). The first index assumes that the knowledge embodied in foreign R\&D stock is a public good; thus a unit of imports incorporates the entire information used for the production of this product whereas this information becomes available in full to all agents in the industry of the recipient country. This index is identical to the one used by Coe and Helpman (1995) and Coe, Helpman, and Hoffmaister (1997) and it is written as:

$$
\mathrm{ISP} 1_{i c t}=\sum_{f} s_{c f t}^{i} R_{i f t},
$$

where $s$ stands for the bilateral import share between country $c$ and $f$ in industry $i$.

The assumption that knowledge transfer to recipients' countries has no limitations is too strong. A large strand of literature (Augier, Cadot, and Dovis 2013; Cameron, Proudman, and Redding 2005; Griffith, Redding, and Van Reenen 2004) argues that the benefit of spillovers is larger if domestic industries have certain characteristics. In that case, to get the spillover effect we need to scale the information transferred with import penetration in industry $i$. Therefore, the second index examines whether the benefit from international knowledge is greater-in two hypothetical recipient countries with the same import share $s$ in industry $i$ - the greater is industry $i$ 's import penetration. The second index is written as:

$$
\mathrm{ISP} 2_{i c t}=\left(\frac{i m p_{i c t}}{x_{i c t}}\right) \sum_{f} s_{c f t}^{i} R_{i f t} .
$$

The ratio $\left(\frac{i m p_{i c t}}{x_{i c t}}\right)$ stands for import penetration.

The third index considers the case that knowledge in the sender country $f$ is not a pure public good; thus the amount of R\&D information transferred in a unit of import from country $f$ to $c$ is limited. To capture the limited transfer, we scale foreign $R \& D$ stock with foreign output. The index is written as:

$$
\mathrm{ISP}_{i c t}=\sum_{f} s_{c f t}^{i}\left(\frac{R_{i f t}}{x_{i f t}}\right) .
$$

The fourth index takes the combination of having both limited transmission of foreign knowledge through a unit of imports and different degree of information availability in industries of recipient countries. In this specification, the amount of indigenous R\&D knowledge 
embodied in importing commodities is larger, the higher is the degree of import penetration in industry $i$ in country $c$. This index is written as:

$$
\mathrm{ISP}_{i c t}=\left(\frac{i m p_{i c t}}{x_{i c t}}\right) \sum_{f} s_{c f t}^{i}\left(\frac{R_{i f t}}{x_{i f t}}\right) .
$$

We construct two indices to capture how domestic industries can benefit from the advanced technological expertise of multinationals affiliates hosted in the domestic economy. ${ }^{12}$ The first index is a measure of horizontal FDI (HFDI), which is defined as the share of inward FDI to output in industry $i$ :

$$
\mathrm{HFDI}_{i c t}=\frac{\mathrm{FDI}_{i c t}^{i n w}}{x_{i c t}},
$$

where $x$ measures output in industry $i$.

There is also scope for vertical FDI (VFDI) knowledge spillovers through knowledge transfer from multinational affiliates in downstream sectors toward industrial suppliers in local upstream sectors in order for the former group to benefit from better quality inputs purchased from the latter. Backward Industrial linkages are measured as per index in Equation (5). The index of VFDI is specified as:

$$
\mathrm{VFDI}_{i c t}=\sum_{i \neq j} \omega_{i j c}\left(\frac{\mathrm{FDI}_{j c t}^{i n w}}{x_{j c t}}\right) .
$$

\section{EMPIRICAL ANALYSIS}

\section{A. Data Coverage}

The period covered is $1987-2007$ for 12 manufacturing industries (ISIC Rev.3 Classification) in 14 OECD countries (Table 1). The number of industries and the level of industry aggregation is mainly dictated from the availability of R\&D data. Production data are taken from EUKLEMS database (2009 release) and the variables used are gross output (GO), total hours worked by employees (H_EMPE), intermediate material inputs (II), and gross fixed capital stock (GFCK). The exact methodology used for the construction of GFCK can be found in Timmer, O'Mahony, and Van Ark (2007). Variables are expressed in constant 1995 prices

12. See Fosfuri, Motta, and Rønde (2001) for theoretical, and Javorcik (2004), Bitzer and Kerekes (2008), Javorcik and Spatareanu (2008), Blalock and Gertler (2008), and Keller and Yeaple (2009) for empirical evidence on FDI-related spillovers.

\begin{tabular}{|c|c|c|}
\hline $\begin{array}{l}\text { Countries-Indexed } \\
\text { with c }\end{array}$ & $\begin{array}{l}\text { Industry } \\
\text { Code } \\
\text { ISIC Rev3 }\end{array}$ & Description \\
\hline Australia & $15 \mathrm{t} 16$ & Food \\
\hline Austria & $17 \mathrm{t} 19$ & Textiles \\
\hline Canada & $21 \mathrm{t} 22$ & $\begin{array}{l}\text { Printing and } \\
\text { publishing }\end{array}$ \\
\hline Denmark & 23 & Coke \\
\hline Spain & 24 & Chemicals \\
\hline Finland & 25 & Rubber and plastics \\
\hline Germany & 26 & Other nonmetallic \\
\hline Italy & $27 \mathrm{t} 28$ & Basic metals \\
\hline Japan & 29 & Machinery \\
\hline Netherlands & $30 \mathrm{t} 33$ & $\begin{array}{l}\text { Electrical and optical } \\
\text { equipment }\end{array}$ \\
\hline Slovenia & $34 \mathrm{t} 35$ & Transport equipment \\
\hline Sweden & $36 \mathrm{t} 37$ & Other manufacturing \\
\hline \multicolumn{3}{|l|}{ UK } \\
\hline USA & & \\
\hline
\end{tabular}

TABLE 1

Data Coverage

Notes: Foreign partners used for the calculation of $R_{i f t}$ are Australia, Austria, Belgium, Canada, Denmark, Finland, France, Germany, Italy, Ireland, Korea, Japan, The Netherlands, Portugal, Spain, Sweden, UK, and USA.

using the following price deflators: output price index (GO_P), capital price index (Ip_GFCF), and material price index (II_P). Then we convert values into USD using PPP exchange rates from OECD-National Accounts.

Data for $R \& D$ expenditure are taken from OECD-ANBERD database. The time span of ANBERD is currently available up to 2007, which basically dictates the time coverage of the whole study. The series of R\&D stock described in the previous section is generated from $R \& D$ expenditures expressed in 2000 USD prices converted with PPP exchange rates. The pool of foreign $R \& D$ stock is calculated from 18 OECD countries and the bilateral import shares specified in Equations (6)-(9) are taken from STAN Bilateral Trade database (2009).

\section{B. Preliminary Evidence}

Figure A1 in Appendix A shows the time trend of output per worker for three representative industries, Chemicals (24), Basic Metals (27t28), and Textiles (17t19). Chemicals are the industry with the highest level of average output per worker, Basic metals are at the middle of productivity distribution, and Textiles are at the bottom. Figure A2 in Appendix A shows output per worker for a selection of countries included in the sample. Accordingly, Germany and the United States have the higher 
TABLE 2

R\&D Stock in 18 OECD Countries, 1987-2007

\begin{tabular}{|c|c|c|c|c|c|c|}
\hline Country & $15 \mathrm{t} 16$ & $17 t 19$ & $21 \mathrm{t} 22$ & 23 & 24 & 25 \\
\hline Australia & 1,369 & 475 & 570 & 78 & 3,073 & 235 \\
\hline Austria & 516 & 72 & 165 & 595 & 360 & 230 \\
\hline Belgium & 686 & 478 & 284 & 427 & 19,990 & 461 \\
\hline Canada & 1,229 & 746 & 1,653 & 1,803 & 7,857 & 429 \\
\hline Denmark & 837 & 35 & 47 & & 3,484 & 155 \\
\hline Finland & 710 & 167 & 508 & 213 & 3,757 & 364 \\
\hline France & 3,553 & 1,129 & 810 & 10,830 & 62,030 & 5,080 \\
\hline Germany & 4,256 & 2,865 & 1,253 & 4,091 & 46,320 & 5,799 \\
\hline Ireland & 461 & 1,265 & 47 & & 941 & 84 \\
\hline Italy & 792 & 357 & 108 & 523 & 7,422 & 3,757 \\
\hline Japan & 19,570 & 8,346 & 5,916 & 8,343 & 194,100 & 18,480 \\
\hline Korea & 862 & 2,098 & 91 & 636 & 4,994 & 2,686 \\
\hline Netherlands & 4,742 & 629 & 169 & 455 & 27,960 & 383 \\
\hline Portugal & 67 & 46 & 158 & 68 & 164 & 3 \\
\hline Spain & 934 & 302 & 255 & 421 & 7,489 & 752 \\
\hline Sweden & 1,222 & 131 & 1,958 & 101 & 10,220 & 395 \\
\hline UK & 5,117 & 1,532 & & 13,960 & 71,070 & 1,275 \\
\hline USA & 23,430 & 6,225 & 16,840 & 86,940 & 308,400 & 14,600 \\
\hline Country & 26 & $27 \mathrm{t} 28$ & 29 & $30 \mathrm{t} 33$ & $34 t 35$ & $36 t 37$ \\
\hline Australia & 380 & 3,793 & 1,134 & 3,890 & 3,149 & 491 \\
\hline Austria & 149 & 233 & 253 & 1,180 & 416 & 68 \\
\hline Belgium & 593 & 4,019 & 2,060 & 12,690 & 1,796 & 437 \\
\hline Canada & 215 & 5,355 & 1,538 & 32,510 & 18,180 & 1,086 \\
\hline Denmark & 1,483 & 257 & 1,757 & 3,339 & 1,012 & 380 \\
\hline Finland & 357 & 1,315 & 2,303 & 6,437 & 993 & 146 \\
\hline France & 2,341 & 12,010 & 9,123 & 81,150 & 107,800 & 1,635 \\
\hline Germany & 7,870 & 5,528 & 60,590 & 41,900 & 61,820 & 1,068 \\
\hline Ireland & 91 & 128 & 154 & 2,333 & 96 & 46 \\
\hline Italy & 577 & 1,206 & 8,169 & 11,920 & 13,580 & 262 \\
\hline Japan & 22,660 & 95,690 & 57,700 & 279,500 & 101,200 & 11,640 \\
\hline Korea & 54 & 1,659 & 20,450 & 28,380 & 9,586 & 296 \\
\hline Netherlands & 163 & 2,642 & 1,965 & 32,070 & 7,680 & 125 \\
\hline Portugal & 14 & 44 & 76 & 357 & 81 & 4 \\
\hline Spain & 503 & 1,635 & 1,800 & 8,353 & 8,945 & 577 \\
\hline Sweden & 276 & 3,284 & 7,251 & 15,310 & 15,560 & 197 \\
\hline UK & 2,341 & 18,440 & 15,950 & 91,120 & 78,490 & 1,214 \\
\hline USA & 23,920 & 72,600 & 51,190 & 673,500 & $1,759,000$ & 8,917 \\
\hline
\end{tabular}

Notes: Values are in millions of 2000 PPP USD. The formulae for the construction of R\&D stock are given in Equations (10)-(12).

average value of output per worker in the period 1987-2007 while countries that can be identified as productivity outliers are Denmark, Finland, and Slovenia. To further understand the distribution of R\&D stock among partners, Table 2 displays average values of $R \& D$ stock by industry for the 18 partners used to calculate the pool of international spillovers. The United States is an R\&D leader with an average stock in most sectors almost triple that of Japan, which is the country with second highest stock in the sample. In Europe, the United Kingdom has the highest R\&D stock on average with France and Germany to follow. Table A1 in Appendix A summarizes statistics for the remaining variables and Table A2 in Appendix A shows pairwise correlations for international spillover index (ISP1-ISP4). As expected, the spillover indices are highly correlated with each other suggesting that they should enter regressions interchangeably to avoid multicollinearity.

\section{Econometric Estimation}

A standard pooled ordinary least squares (POLS) estimator requires the error term $\left(u_{i c t}\right)$ to be uncorrelated both over time and across individual cross-sections. The dedicated knowledge spillovers literature ignores the importance of cross-sectional dependence (CD) in the error term when estimating specifications similar to Equation (4), which can lead to substantial downward bias in the spillover effect. ${ }^{13}$. If one ignores CD corr $\left(u_{i t} u_{j t}\right)=\rho$, where $\rho \neq 0$ for industry $i \neq j$ then the issue raised is whether spillover variables in the production function measure knowledge externalities or just reflect data dependencies due to misspecification and cross-sectional heterogeneity (Kapetanios, Pesaran, and Yamagata 2011). Eberhardt, Helmers, and Strauss (2013) point out that if estimation does not account for $\mathrm{CD}$ then resulting estimates more likely cofound the true effect of own R\&D capital ( $r$ ) with what might be a mix of spillover effects and other unobserved phenomena. To illustrate the case of $\mathrm{CD}$ in the error term, consider the model:

$$
y_{i t}=b_{0 i}+\mathbf{b}^{\prime} \mathbf{X}_{i t}+u_{i t} .
$$

Parameter $b_{0}$ is an intercept that imposes homogeneity for simplicity of exposition; this can be extended to include observed common effects, such as year and country dummies. $\mathbf{X}$ is a vector of $(k \times 1)$ regressors' inputs and $\mathbf{b}^{\prime}$ are parameters to be estimated. The multifactor structure of the error term due to $\mathrm{CD}$ is now described as: $u_{i t}=\lambda^{\prime} \boldsymbol{\rho}_{i}+\epsilon_{i t}$, where $\boldsymbol{\rho}_{i}$ is the $(m \times 1)$ unobserved common factor effects and $\epsilon$ is the standard idiosyncratic error independently distributed of $\mathbf{X}$. The estimation technique must account for nonzero loadings in $\boldsymbol{\rho}$, otherwise the estimates are biased and inconsistent (Coakley, Fuertes, and Smith 2006).

We first test for CD in Equation (4) following the study by Pesaran (2004), which develops a pair-wise correlation coefficient in OLS residuals without controlling for CD. Table 3 reports $\mathrm{CD}$ results for specification (Equation (4)) that includes spillovers indices (Equation (5)-(9)) interchangeably. The null hypothesis $\mathrm{H}_{0}: \rho_{i j}=\rho_{j i}=\operatorname{cov}\left(\hat{u}_{i t} \hat{u}_{j t}\right)=0$ for industry $i \neq j$ is easily rejected in all specifications indicating the existence of CD in our data.

13. In a production function like Equation (4), industries can be subject to common unobserved macroeconomic shocks in year $t$. Therefore, empirical estimation should be able to establish real knowledge spillover effects that are disentangled from data dependencies due to empirical misspecification. 
TABLE 3

Cross-Section Dependence (CD) Test-Pesaran (2004)

\begin{tabular}{lcccc}
\hline Model & $\begin{array}{c}\text { CD } \\
\text { Test }\end{array}$ & $\boldsymbol{p}$ Value & Corr & $\begin{array}{c}\text { Abs } \\
\text { (Corr) }\end{array}$ \\
\hline Specification with ISP1 & 50.52 & .00 & .109 & .557 \\
Specification with ISP2 & 51.49 & .00 & .124 & .555 \\
Specification with ISP3 & 53.31 & .00 & .115 & .556 \\
Specification with ISP4 & 53.69 & .00 & .129 & .558 \\
\hline
\end{tabular}

We also test for serial correlation in the residuals using the Arellano and Bond (1991) test; results are shown in Table A3 in Appendix B.

We now turn to the estimation technique of Equation (4) in the presence of CD. Pesaran (2006) augments the POLS estimator with crosssectional average of both $y$ and $\mathbf{X}$ to proxy for the linear combination of unobserved common effects. We refer to this estimator as the Common Correlated Effects Mean Group Estimator $(\mathrm{CCEMG}),{ }^{14}$ which allows for unobservables to have a different impact across $i$ (Appendix B). Results from CCEMG are shown in Table 4.

Another source of bias for Equation (4) is the existence of systematic feedback effects between output and production inputs. The exogeneity assumption might still fail if one assumes that higher productivity is likely to impact on industry's future purchase of inputs. This implies: $E\left(u_{i c t+1} \mid k_{i c t}\right) \neq 0$ and $E\left(u_{i c t+1} \mid m_{i c t}\right) \neq 0$ where $E$ is the conditional expectations operator. In other words, an unobserved mechanism can drive the error term in Equation (4) and inputs, causing simultaneity bias. A similar interpretation of endogeneity applies for the spillover variables. To relax this moment condition, we use an instrumental two-step generalized method of moments (GMM) estimator. The GMM estimator also controls for unobserved measurement errors in the construction of all variables in Equation (4). Given the evidence of no serial correlation in second and thirds lags, we use as instruments values of the endogenous variables in periods $(t-2)$ and $(t-3)$ under the assumption that productivity shocks at time $t$ are uncorrelated with input choices in previous periods. The validity of the instruments is assessed by the LM test (Anderson 1984) of underidentification and the Hansen J test (Hansen 1982) of overidentifying restrictions. As shown at the bottom of Table 5, we

14. Monte Carlo experiments in the study by Pesaran (2006) show the asymptotic efficiency of CCEMG under slope heterogeneity.
TABLE 4

Common Correlated Effects Mean Group Estimator (CCEMG) - Equation (4)

\begin{tabular}{lcccc}
\hline & $\mathbf{1}$ & $\mathbf{2}$ & $\mathbf{3}$ & $\mathbf{4}$ \\
\hline$k$ & $0.390^{* * *}$ & $0.400^{* * *}$ & $0.374 * * *$ & $0.399^{* * *}$ \\
& $(0.02)$ & $(0.02)$ & $(0.02)$ & $(0.03)$ \\
$m$ & $0.410^{* * *}$ & $0.389^{* * *}$ & $0.391^{* * *}$ & $0.388^{* * *}$ \\
& $(0.02)$ & $(0.02)$ & $(0.02)$ & $(0.02)$ \\
$h$ & $0.033^{* * *}$ & 0.026 & $0.033^{*}$ & $0.043^{* * *}$ \\
& $(0.02)$ & $(0.02)$ & $(0.02)$ & $(0.02)$ \\
$r$ & $0.186^{* * *}$ & $0.130^{* * *}$ & $0.153^{* * *}$ & $0.143 * * *$ \\
& $(0.03)$ & $(0.03)$ & $(0.03)$ & $(0.03)$ \\
DSP & 0.006 & 0.005 & 0.004 & 0.003 \\
& $(0.01)$ & $(0.01)$ & $(0.01)$ & $(0.01)$ \\
ISP1 & $0.036^{* *}$ & & & \\
& $(0.02)$ & & & \\
ISP2 & & $0.029 * *$ & & \\
& & $(0.01)$ & & \\
ISP3 & & & $0.01 * *$ & \\
& & & $(0.01)$ & \\
ISP4 & & & & $0.01 *$ \\
& & & & \\
$C R S$ & $36.85 / 0.00$ & $42.66 / 0.00$ & $41.15 / 0.00$ & $42.74 / 0.00$ \\
$N$ & 2,753 & 2,753 & 2,753 & 2,753 \\
$N \_g$ & 152.000 & 152.000 & 152.000 & 152.000 \\
Avg_n & 18.112 & 18.112 & 18.112 & 18.112 \\
$\chi^{2}$ & 650.962 & 644.643 & 663.482 & 660.111 \\
\hline
\end{tabular}

Notes: Robust standard errors in parentheses with $* p<0.10, * * p<0.05, * * * p<0.01$. The dependent variable $q$ is the log of gross output per hour worked. Regressions include an intercept and year-fixed effects. CRS refers to constant returns to scale for capital and materials, $\chi^{2}(1)$ and $p$ values are reported. Coefficients of cross-section average regressors are not reported as they are not interpretable in an economically meaningful way. They only capture the impact of the unobserved common factor. $N \_g$ is the total number of observations in each cross-section. $A v g \_n$ is the number of observations for regressions from which these averages are constructed.

cannot reject the null hypothesis of instrument validity while the null hypothesis of the LM test that the matrix of reduced-form coefficients in the first-stage regression is underidentified, is rejected at high levels of significance.

\section{RESULTS}

\section{A. Results from CCEMG and GMM}

We begin by focusing on CCEMG results in Table 4: the coefficients of capital and materials are between 0.39 and 0.40 ; the assumption of constant returns to scale (CRS) is rejected as pointed out at the bottom of the table. Note CCEMG is taking into account panel heterogeneity and the estimates shown in Table 4 are cross-section averages. This means that the picture for individual cross-sections might vary substantially but one should be cautious in 
TABLE 5

GMM Estimator-Equation (4)

\begin{tabular}{|c|c|c|c|c|}
\hline & 1 & 2 & 3 & 4 \\
\hline$k$ & $\begin{array}{c}0.636 * * * \\
(0.06)\end{array}$ & $\begin{array}{c}0.676 * * * \\
(0.06)\end{array}$ & $\begin{array}{c}0.648 * * * \\
(0.06)\end{array}$ & $\begin{array}{c}0.669 * * * \\
(0.06)\end{array}$ \\
\hline$m$ & $\begin{array}{c}0.633 * * * \\
(0.02)\end{array}$ & $\begin{array}{c}0.623 * * * \\
(0.02)\end{array}$ & $\begin{array}{c}0.650 * * * \\
(0.02)\end{array}$ & $\begin{array}{c}0.633 * * * \\
(0.02)\end{array}$ \\
\hline$h$ & $\begin{array}{c}0.084 * * * \\
(0.02)\end{array}$ & $\begin{array}{c}0.080 * * * \\
(0.02)\end{array}$ & $\begin{array}{c}0.062 * \\
(0.03)\end{array}$ & $\begin{array}{c}0.071 * * * \\
(0.03)\end{array}$ \\
\hline$r$ & $\begin{array}{c}0.048^{* * *} \\
(0.01)\end{array}$ & $\begin{array}{c}0.046^{* * *} \\
(0.01)\end{array}$ & $\begin{array}{c}0.048 * * \\
(0.00)\end{array}$ & $\begin{array}{c}0.052^{* * *} \\
(0.00)\end{array}$ \\
\hline DSP & $\begin{array}{l}0.014 \\
(0.01)\end{array}$ & $\begin{array}{l}0.015 \\
(0.01)\end{array}$ & $\begin{array}{c}0.029 * * \\
(0.01)\end{array}$ & $\begin{array}{c}0.023 * * \\
(0.01)\end{array}$ \\
\hline ISP1 & $\begin{array}{c}0.025 * * \\
(0.01)\end{array}$ & & & \\
\hline ISP2 & & $\begin{array}{c}0.022 * \\
(0.01)\end{array}$ & & \\
\hline ISP3 & & & $\begin{array}{c}0.065 * * * \\
(0.02)\end{array}$ & \\
\hline ISP4 & & & & $\begin{array}{c}0.024 * * * * \\
(0.01)\end{array}$ \\
\hline$N$ & 2,502 & 2,428 & 2,352 & 2,278 \\
\hline Adj. $R^{2}$ & 0.9986 & 0.9986 & 0.9984 & 0.9985 \\
\hline$F$ & 13101.77 & 13799.04 & 7911.88 & 11975.99 \\
\hline Hansen test & 10.02 & 14.69 & 11.54 & 15.72 \\
\hline$p$ value & 0.44 & 0.26 & 0.64 & 0.26 \\
\hline LM test & 4605.81 & 4447.14 & 152.30 & 1922.60 \\
\hline$p$ value & 0.00 & 0.00 & 0.00 & 0.00 \\
\hline
\end{tabular}

Notes: Clustered robust standard errors in parentheses with $* p<0.10$, ** $p<0.05$, *** $p<0.01$. The dependent variable $q$ is the $\log$ of gross output per worker. All specifications are estimated with the two step feasible GMM estimator. The instruments used are $k, m, h, r$, DSP, and ISP in periods $(t-2)$ and $(t-3)$. Regressions include an intercept, country, industry, and time-fixed effects. The Hansen statistic of overidentification tests whether the included instruments as a set are valid, and thus exogenous. The LM test is a likelihood ratio test of underidentification referring to whether excluded instruments are relevant.

drawing inference from individual cross-section estimates (Pedroni 2007). Indicatively, Table A4 in Appendix C lists coefficients for the 12 individual industries. Accordingly, $25 \%$ of industries exhibit increasing returns to scale, $15 \%$ exhibit constant returns, while the remaining $60 \%$ operate under decreasing returns.

The coefficient of human capital $(h)$ is positive as expected and statistically significant in all specifications of Table 4. The elasticity of output with respect to human capital is between $2.6 \%$ and $4.3 \%$. This result complies quite well with findings from cross-country estimates about the role of human capital on productivity measures (Benhabib and Spiegel 1994; Miller and Upadhyay 2000). The impact of industry's own R\&D stock $r$ is positive and statistically significant in all columns of Table 4 . The coefficient of $r$ is between .13 and .186, which indicates an R\&D elasticity of $18.6 \%$ at the highest end. With regard to $r$ in the GMM estimates of Table 5, the coefficient is again statistically significant but with a lower magnitude at the range of $4.6 \%-5.2 \%$. R\&D elasticities from both CCEMG and GMM are in line with previous firm level studies (Bartelsman 1990; Hall and Mairesse 1995; Rogers 2010) but lower from industry level studies (Higón 2007 [i.e., 33\%]; Acharya and Keller 2009 [i.e., 27\%]). Regarding DSP, the coefficient is found to be statistically insignificant in all but two specifications. The finding of insignificant domestic spillovers is compatible with the core proposition of the neoclassical trade theory that assumes no (if not negative) cross-industry productivity effects (Harrigan 1997; Nickell, Redding, and Swaffield 2008) while it contradicts Branstetter's finding (2001) of learning gains from the innovative activity of other domestic counterparts. A more technical reason for the insignificance of the DSP coefficient is likely to be the inappropriateness of input-output tables to capture the true degree of interaction across domestic industries.

Turning to the estimates of international spillovers ISP1-ISP4, the results are positive and significant in all specifications. In the CCEMG estimator, the knowledge spillover has elasticity between $1 \%$ and $3.6 \%$. The size of this elasticity is $3.6 \%$ if we assume that the entire amount of knowledge embodied in foreign R\&D stock was transferred through imports. ${ }^{15}$ If we assume that the effect of spillover is analogous to the degree of import intensity in the domestic industry, the elasticity declines to $2.6 \%$. With more restrictive assumptions about the amount of knowledge transferred from source to destination the elasticity is reduced even more to $1 \%$. These results indicate that there are spillover effects even after controlling for the presence of $\mathrm{CD}-\mathrm{a}$ key omission of the previous literature - whose size depends on the assumption made about the amount of information sent and received through importing commodities. Our results regarding the importance of imports as a transmission channel of knowledge are compatible with Ang and Madsen's (2013) findings while they stand somewhere in the middle from Keller (2002) to Acharya and Keller (2009) on the one hand, who find foreign spillovers often to exceed domestic R\&D gains, and Eberhardt, Helmers, and

15. This elasticity value is almost identical to the total unweighted foreign R\&D stock elasticity found by Coe and Helpman (1995) and Coe, Helpman, and Hoffmaister (2009). 
Strauss (2013) on the other hand, who conclude that spillovers are inseparable from industry's own $R \& D$ when $C D$ is taken into account. The CCEMG estimates indicate that the effect of spillovers is significantly lower from own $\mathrm{R} \& \mathrm{D}$ but the former is far from being viewed as negligible. In the GMM results (Table 5), the elasticity of output per worker with respect to spillover variables is always half of that of $r$ with the exception of specification 3 . The long-run importance of international spillovers to productivity is vital even after controlling for standard endogeneity bias in the production function. This pattern of elasticity coefficients between industry's own R\&D and international spillovers signifies the existence of adjustment costs in incorporating external knowledge in the domestic production. These costs more likely reflect the nature of international R\&D competition and issues of appropriability that deteriorate the effectiveness of foreign R\&D stock.

\section{B. Seemingly Unrelated Regression Estimates and Results for Low and High Technology Groups}

In the presence of industry heterogeneity ${ }^{16}$ and $\mathrm{CD}$ in the residuals, another feasible estimator is the seemingly unrelated regression (SUR), which allows coefficients to vary across industries. The CCEMG estimator in Table 5 assumes heterogeneity; nonetheless we can estimate Equation (4) for each individual industry using SUR to obtain a more comprehensive idea about the effect of R\&D in each specific industry. This approach also permits us to explore whether the pattern of results varies if we divide industries into groups of low and high technology. For the sake of comparability of our results to other studies, we show and discuss results only for the ISP1, which is identical to what has been used as a spillover index in the literature so far. ${ }^{17}$

With reference to traditional inputs, chisquared test in the last column of Table 6 indicates that only 3 out of 12 industries exhibit

16. The Breusch and Pagan (1979) statistic $(9,876 / p=.00)$ rejects the null hypothesis of panel homogeneity (zero variance in $u$ ) across cross-sections indicating the existence of substantial differences across industries and countries.

17. SUR estimates for the remaining indices ISP2, ISP3, and ISP4 are qualitatively very similar with only minor variations and are not shown in the paper. They are available from the authors upon request. constant returns to scale. Turning to the variables of primary interest, Table 6 confirms the existence of substantial heterogeneity across industries as far as the impact of own $R \& D$ $(r)$ and spillovers is concerned. The effect of own industry's R\&D is positive and statistically significant in the high tech group (Chemicals, Machinery, Electrical equipment, and Transport) plus three industries from the low tech group. Regarding DSP, coefficients are positive and statistically significant in 3 out of 12 industries overall. The coefficient of ISP1 is significant only in the group of high tech industries with the highest elasticity to be in Chemicals and Electrical Equipment $(13.5 \%$ and $14.6 \%$, respectively). These results indicate that international exchange of ideas tends to benefit more high tech industries while low tech industries are less capable of absorbing productivity gains from foreign knowledge stock. The lack of absorptive capacity in the low tech group is mainly due to limitations within industry R\&D activity, which becomes an impediment in facilitating technological advancements.

\section{FDI-Related Spillovers}

The empirical approach that associates FDI with knowledge spillovers relies on microeconometric evidence, which assumes that any measure of FDI embodies the amount of knowledge and ideas existing in multinational subsidiaries (Aitken and Harrison 1999; Haskel, Pereira, and Slaughter 2007; Keller 2010; Xu 2000). Javorcik (2008) finds evidence of substantial technological externalities from FDI that impact on domestically owned firms, which can further boost aggregate industry productivity. Nonetheless, the literature of FDI spillovers is rather puzzling as recent studies are not always conclusive with some of them (Blalock and Gertler 2008; Javorcik and Spatareanu 2008) documenting negative FDI effects on domestic productivity. Aitken and Harrison (1999) attribute the negative impact of FDI to inverse effects induced from foreign competition. However, studies with negative results of FDI on domestic productivity use standard within-fixed effects estimators without controlling for $\mathrm{CD}$ in the panel or for potential endogeneity bias between FDI decisions and domestic productivity.

The approach of the present study is to replicate specification (Equation (4)) with CCEMG and GMM estimators including indices of HFDI and VFDI. For comparability, Tables 7 
TABLE 6

SUR Estimates for Individual Industries - Equation (4)

\begin{tabular}{|c|c|c|c|c|c|c|c|}
\hline & $k$ & $m$ & $h$ & $r$ & DSP & ISP1 & CRS \\
\hline \multicolumn{8}{|l|}{ High tech group } \\
\hline Chemicals & $\begin{array}{c}0.666 * * * \\
(0.03)\end{array}$ & $\begin{array}{c}0.462 * * * \\
(0.03)\end{array}$ & $\begin{array}{c}0.054 * * \\
(0.033)\end{array}$ & $\begin{array}{c}0.1353 \\
(0.00)\end{array}$ & $\begin{array}{c}-0.0314 \\
(0.01)\end{array}$ & $\begin{array}{c}0.072 * \\
(0.04)\end{array}$ & $\begin{array}{c}3.50 \\
(0.06)\end{array}$ \\
\hline Machinery & $\begin{array}{c}0.725 * * * \\
(0.04)\end{array}$ & $\begin{array}{c}0.464 * * * \\
(0.02)\end{array}$ & $\begin{array}{c}0.0363 * * \\
(0.02)\end{array}$ & $\begin{array}{c}0.0238^{*} \\
(0.01)\end{array}$ & $\begin{array}{c}-0.0228 \\
(0.01)\end{array}$ & $\begin{array}{c}0.330 * * * \\
(0.04)\end{array}$ & $\begin{array}{c}262.39 \\
(0.00)\end{array}$ \\
\hline Electrical equipment & $\begin{array}{c}0.194 * * * \\
(0.05)\end{array}$ & $\begin{array}{c}-0.177 * * * \\
(0.03)\end{array}$ & $\begin{array}{c}0.264^{*} \\
(0.1)\end{array}$ & $\begin{array}{c}0.146^{* * * *} \\
(0.04)\end{array}$ & $\begin{array}{c}0.0718 \\
(0.05)\end{array}$ & $\begin{array}{c}0.132 * \\
(0.05)\end{array}$ & $\begin{array}{c}0.88 \\
(0.34)\end{array}$ \\
\hline Transport equipment & $\begin{array}{c}0.573 * * * \\
(0.05)\end{array}$ & $\begin{array}{c}0.405 * * * \\
(0.02)\end{array}$ & $\begin{array}{c}-0.003 \\
(0.03)\end{array}$ & $\begin{array}{c}0.0210^{*} \\
(0.01)\end{array}$ & $\begin{array}{c}-0.0332 \\
(0.018)\end{array}$ & $\begin{array}{c}0.018^{* *} \\
(0.01)\end{array}$ & $\begin{array}{c}31.6 \\
(0.00)\end{array}$ \\
\hline \multicolumn{8}{|l|}{ Low tech group } \\
\hline Food & $\begin{array}{c}0.980 * * * \\
(0.05)\end{array}$ & $\begin{array}{c}0.413 * * * \\
(0.03)\end{array}$ & $\begin{array}{c}-0.021 \\
(0.01)\end{array}$ & $\begin{array}{c}-0.065 * * * \\
(0.00)\end{array}$ & $\begin{array}{c}0.066^{* * * *} \\
(0.01)\end{array}$ & $\begin{array}{c}-0.004 \\
(0.03)\end{array}$ & $\begin{array}{c}3.83 \\
(0.05)\end{array}$ \\
\hline Textiles & $\begin{array}{c}0.514 * * * \\
(0.04)\end{array}$ & $\begin{array}{c}0.557 * * * \\
(0.03)\end{array}$ & $\begin{array}{c}0.015^{* *} \\
(0.02)\end{array}$ & $\begin{array}{c}-0.036^{*} \\
(0.01)\end{array}$ & $\begin{array}{l}0.003 \\
(0.02)\end{array}$ & $\begin{array}{l}0.115 \\
(0.07)\end{array}$ & $\begin{array}{c}2.91 \\
(0.08)\end{array}$ \\
\hline Printing & $\begin{array}{c}0.327 * * * \\
(0.03)\end{array}$ & $\begin{array}{c}0.421 * * * \\
(0.03)\end{array}$ & $\begin{array}{c}0.063 * * \\
(0.03)\end{array}$ & $\begin{array}{c}0.0405^{* *} * \\
(0.01)\end{array}$ & $\begin{array}{c}0.084 * * * \\
(0.02)\end{array}$ & $\begin{array}{l}0.019 \\
(0.02)\end{array}$ & $\begin{array}{c}183 \\
(0.00)\end{array}$ \\
\hline Coke & $\begin{array}{c}0.389 * * * \\
(0.04)\end{array}$ & $\begin{array}{c}0.415^{*} * * \\
(0.02)\end{array}$ & $\begin{array}{c}0.075 * * \\
(0.06)\end{array}$ & $\begin{array}{c}-0.195 * * * \\
(0.01)\end{array}$ & $\begin{array}{c}0.151 * * \\
(0.05)\end{array}$ & $\begin{array}{c}-0.059^{*} \\
(0.03)\end{array}$ & $\begin{array}{c}0.54 \\
(0.46)\end{array}$ \\
\hline Rubber and plastics & $\begin{array}{c}0.678 * * * \\
(0.05)\end{array}$ & $\begin{array}{c}0.462 * * * \\
(0.03)\end{array}$ & $\begin{array}{c}0.023^{* *} * \\
(0.03)\end{array}$ & $\begin{array}{c}-0.0779 * * \\
(0.02)\end{array}$ & $\begin{array}{c}-0.045 \\
(0.01)\end{array}$ & $\begin{array}{c}-0.082 * \\
(0.05)\end{array}$ & $\begin{array}{c}2.76 \\
(0.09)\end{array}$ \\
\hline Nonmetallic miner. & $\begin{array}{c}0.473 * * * \\
(0.04)\end{array}$ & $\begin{array}{c}0.426^{* * * *} \\
(0.04)\end{array}$ & $\begin{array}{c}-0.0448 \\
(0.02)\end{array}$ & $\begin{array}{c}0.146^{* * *} * \\
(0.02)\end{array}$ & $\begin{array}{c}0.005^{*} \\
(0.02)\end{array}$ & $\begin{array}{c}0.0963 * * \\
(0.04)\end{array}$ & $\begin{array}{c}0.06 \\
(0.34)\end{array}$ \\
\hline Basic metals & $\begin{array}{c}0.578 * * * \\
(0.02)\end{array}$ & $\begin{array}{c}0.564 * * * \\
(0.02)\end{array}$ & $\begin{array}{c}0.007^{*} \\
(0.02)\end{array}$ & $\begin{array}{c}0.006^{*} \\
(0.00)\end{array}$ & $\begin{array}{c}-0.019 \\
(0.00)\end{array}$ & $\begin{array}{c}-0.066^{*} \\
(0.03)\end{array}$ & $\begin{array}{l}17.03 \\
(0.00)\end{array}$ \\
\hline Other manufacturing & $\begin{array}{c}0.364 * * * \\
(0.06)\end{array}$ & $\begin{array}{c}0.401 * * * \\
(0.03)\end{array}$ & $\begin{array}{c}-0.0372 \\
(0.02)\end{array}$ & $\begin{array}{c}0.0465 * * \\
(0.01)\end{array}$ & $\begin{array}{c}-0.049 \\
(0.02)\end{array}$ & $\begin{array}{c}-0.04 * * * \\
(0.05)\end{array}$ & $\begin{array}{l}26.11 \\
(0.00)\end{array}$ \\
\hline
\end{tabular}

Notes: Standard errors in parentheses with $* p<0.10, * * p<0.05, * * * p<0.01$. Number of observations: 197 . The dependent variable $q$ is the log of gross output per hour worked. Regressions include an intercept, country, and time-fixed effects. CRS refers to the hypothesis of constant returns to scale: $H_{0}: \alpha_{2}+\alpha_{3}=1$.

and 8 show estimates from specifications that include both import and FDI spillovers. The number of observations is now smaller as FDI data are available from 1990 onwards. Table 7 reports CCEMG estimates and shows the existence of statistically significant HFDI effects on productivity. The estimates of HFDI are in the order of $1.6 \%-1.8 \%$ while the coefficients of importinduced spillovers are between $0.08 \%$ and $1.5 \%$. When Equation (4) is estimated with GMM using as instruments the values of endogenous variables in periods $(t-2)$ and $(t-3)$, HFDI coefficients are in the range of $1.8 \%-3.4 \%$ and again slightly higher than ISP coefficients which are between $1 \%$ and $1.2 \%$ across all specifications. Turning to VFDI spillovers, all coefficients are statistically different from zero in the CCEMG Table 7 but their economic impact (i.e., $0.07 \%$ and $0.08 \%$ ) is smaller from both HFDI and import-induced spillovers. The VFDI estimates are turned insignificant in the GMM estimates in Table 8. Our HFDI results are in line with Keller and Yeaple (2009) - though with a much smaller FDI elasticity in the present study — whose analysis also confirms the existence of HFDI spillovers contrary to previous studies. Our results are different from the previous literature in the sense that it fails to find positive FDI spillovers on productivity because we draw evidence from an OECD sample where absorptive capacity is - by default-stronger from that of developing countries. With reference to the weak effect of VFDI, which becomes insignificant when endogeneity bias is accounted for, our justification lies within two reasons: first the current VFDI index uses input-output table to measure the interaction across industries but this can be a misleading approach if multinationals do not have the same pattern of sourcing with domestic industries. The second reason stresses that technology transfer through VFDI is not free of charge and thus cannot be easily identifiable from indices that measure the presence of FDI in upstream and downstream industries (Keller 2010). To capture knowledge spillovers from VFDI, we need to subtract from the local supplier's revenue any contractual payment for selling materials and services to multinationals. This artifact measurement issue can only be addressed with information from firm or plant level data. 
TABLE 7

FDI Spillovers —Common Correlated Effects Mean Group Estimator (CCEMG)—Equation (4)

\begin{tabular}{|c|c|c|c|c|c|c|c|c|}
\hline & 1 & 2 & 3 & 4 & 5 & 6 & 7 & 8 \\
\hline$k$ & $\begin{array}{c}0.340 * * * \\
(0.04)\end{array}$ & $\begin{array}{c}0.373 * * * \\
(0.03)\end{array}$ & $\begin{array}{c}0.357 * * * \\
(0.03)\end{array}$ & $\begin{array}{c}0.391 * * * \\
(0.03)\end{array}$ & $\begin{array}{c}0.368 * * * \\
(0.03)\end{array}$ & $\begin{array}{c}0.397 * * * \\
(0.03)\end{array}$ & $\begin{array}{c}0.403 * * * \\
(0.04)\end{array}$ & $\begin{array}{c}0.411 * * * \\
(0.03)\end{array}$ \\
\hline$m$ & $\begin{array}{c}0.374 * * * \\
(0.03)\end{array}$ & $\begin{array}{c}0.395 * * * \\
(0.03)\end{array}$ & $\begin{array}{c}0.354 * * * \\
(0.03)\end{array}$ & $\begin{array}{c}0.394 * * * \\
(0.03)\end{array}$ & $\begin{array}{c}0.341 * * * \\
(0.03)\end{array}$ & $\begin{array}{c}0.380 * * * \\
(0.03)\end{array}$ & $\begin{array}{c}0.364 * * * \\
(0.03)\end{array}$ & $\begin{array}{c}0.419 * * * \\
(0.03)\end{array}$ \\
\hline$h$ & $\begin{array}{c}0.053 * * \\
(0.03)\end{array}$ & $\begin{array}{l}0.024 \\
(0.03)\end{array}$ & $\begin{array}{l}0.010 \\
(0.02)\end{array}$ & $\begin{array}{l}0.032 \\
(0.02)\end{array}$ & $\begin{array}{l}0.002 \\
(0.02)\end{array}$ & $\begin{array}{l}0.014 \\
(0.02)\end{array}$ & $\begin{array}{l}0.003 \\
(0.03)\end{array}$ & $\begin{array}{l}0.020 \\
(0.03)\end{array}$ \\
\hline$r$ & $\begin{array}{c}0.222 * * * \\
(0.04)\end{array}$ & $\begin{array}{c}0.159 * * * \\
(0.04)\end{array}$ & $\begin{array}{c}0.162 * * * \\
(0.04)\end{array}$ & $\begin{array}{c}0.163 * * * \\
(0.04)\end{array}$ & $\begin{array}{c}0.195 * * * \\
(0.04)\end{array}$ & $\begin{array}{c}0.189 * * * \\
(0.04)\end{array}$ & $\begin{array}{c}0.152 * * * \\
(0.04)\end{array}$ & $\begin{array}{c}0.145^{*} * * \\
(0.04)\end{array}$ \\
\hline DSP & $\begin{array}{c}-0.015 \\
(0.10)\end{array}$ & $\begin{array}{c}0.20^{* *} \\
(0.08)\end{array}$ & $\begin{array}{l}0.008 \\
(0.09)\end{array}$ & $\begin{array}{c}0.11 \\
(0.06)\end{array}$ & $\begin{array}{l}-0.13 \\
(0.08)\end{array}$ & $\begin{array}{c}0.10 \\
(0.07)\end{array}$ & $\begin{array}{l}-0.11 \\
(0.07)\end{array}$ & $\begin{array}{c}0.09 \\
(0.07)\end{array}$ \\
\hline ISP1 & $\begin{array}{c}0.014 * * * \\
(0.00)\end{array}$ & $\begin{array}{c}0.013 * * * \\
(0.00)\end{array}$ & & & & & & \\
\hline ISP2 & & & $\begin{array}{c}0.015 * * * \\
(0.00)\end{array}$ & $\begin{array}{c}0.012 * * * \\
(0.00)\end{array}$ & & & & \\
\hline ISP3 & & & & & $\begin{array}{c}0.008 * * \\
(0.00)\end{array}$ & $\begin{array}{l}0.006 \\
(0.00)\end{array}$ & & \\
\hline ISP4 & & & & & & & $\begin{array}{c}0.015 * * * \\
(0.00)\end{array}$ & $\begin{array}{c}0.009 * * * \\
(0.00)\end{array}$ \\
\hline HFDI & $\begin{array}{c}0.017 * * * \\
(0.00)\end{array}$ & & $\begin{array}{c}0.018 * * * \\
(0.00)\end{array}$ & & $\begin{array}{c}0.016^{* * * *} \\
(0.00)\end{array}$ & & $\begin{array}{c}0.017 * * * \\
(0.00)\end{array}$ & \\
\hline VFDI & & $\begin{array}{c}0.008 * * \\
(0.00)\end{array}$ & & $\begin{array}{c}0.008 * * \\
(0.00)\end{array}$ & & $\begin{array}{c}0.007 * * \\
(0.00)\end{array}$ & & $\begin{array}{c}0.007 * * \\
(0.00)\end{array}$ \\
\hline$N$ & 1,907 & 1,981 & 1,907 & 1,981 & 1,907 & 1,981 & 1,907 & 1,981 \\
\hline$N \_\mathrm{g}$ & 115.000 & 119.000 & 115.000 & 119.000 & 115.000 & 119.000 & 115.000 & 119.000 \\
\hline g_avg & 16.583 & 16.647 & 16.583 & 16.647 & 16.583 & 16.647 & 16.583 & 16.647 \\
\hline$\chi^{2}$ & 262.224 & 322.843 & 303.309 & 333.198 & 282.875 & 385.661 & 284.460 & 385.230 \\
\hline
\end{tabular}

Notes: Robust standard errors in parentheses with $* p<0.10,{ }^{*} p<0.05, * * * p<0.01$. The dependent variable $q$ is the $\log$ of gross output per hour worked. Regressions include an intercept and year-fixed effects. Coefficients of cross-section average regressors are not reported as they are not interpretable in an economically meaningful manner. They only capture the impact of the unobserved common factor. $N$ is the total number of observations in each cross-section. Avg $n$ is the number of observations for regressions from which these averages are constructed.

\section{Knowledge Spillovers and Protection of Intellectual Property Rights}

This section examines whether country specific institutions affect FDI knowledge spillovers. More specifically, we focus on two different institutional aspects: (1) the patent protection legislation and (2) the ease of doing business. In a Schumpeterian growth model, a firm's decision to innovate depends on the difference between post- and preinnovation rents (Aghion, Howitt, and Prantl 2015). Postinnovation rents are primarily determined from the legal system of patent protection. Likewise, technology transfer from an MNC's headquarters toward its local subsidiaries is heavily dependent on recipient country's legal system. An environment with increased protection of patent rights can stimulate MNC technology transfer making local subsidiaries more innovative compared to domestic firms, and hence inward FDI is upgraded to a major productivity driver. Park and Lippoldt (2005) claim that increased protection of intellectual property rights (i.e., copyrights on books, music, software, patent rights on inventions, and trademark rights on business symbols and names) encourage rights holders to be less restrained of international technology transfer. ${ }^{18}$

The objective of our econometric specification is to unveil whether spillover effects from HFDI and VFDI are affected by the strength of patent protection and the ease of doing business. The institutional indices are country-specific without industry variation. The index of patent protection (Rights) is developed by Park and Lippoldt (2005) and takes values from zero (weakest) to five (strongest). It is an unweighted sum of five separate scores for coverage (inventions that are patentable; membership in international treaties; duration of protection; enforcement

18. These considerations are empirically confirmed by Schneider (2005) who shows that the legal system positively affects the innovation rate with this effect becoming stronger in developed countries, while Coe, Helpman, and Hoffmaister (2009) show that the legal system affects the outcome of the innovative activity by determining the type of R\&D undertaken. 
TABLE 8

FDI Spillovers - GMM Estimator-Equation (4)

\begin{tabular}{|c|c|c|c|c|c|c|c|c|}
\hline & 1 & 2 & 3 & 4 & 5 & 6 & 7 & 8 \\
\hline$k$ & $\begin{array}{c}0.668 * * * \\
(0.04)\end{array}$ & $\begin{array}{c}0.670 * * * \\
(0.04)\end{array}$ & $\begin{array}{c}0.679 * * * \\
(0.03)\end{array}$ & $\begin{array}{c}0.684 * * * \\
(0.03)\end{array}$ & $\begin{array}{c}0.673 * * * \\
(0.04)\end{array}$ & $\begin{array}{c}0.673 * * * \\
(0.04)\end{array}$ & $\begin{array}{c}0.682 * * * \\
(0.04)\end{array}$ & $\begin{array}{c}0.686^{* * * *} \\
(0.04)\end{array}$ \\
\hline$m$ & $\begin{array}{c}0.597 * * * \\
(0.01)\end{array}$ & $\begin{array}{c}0.605 * * * \\
(0.01)\end{array}$ & $\begin{array}{c}0.590 * * * \\
(0.01)\end{array}$ & $\begin{array}{c}0.601 * * * \\
(0.01)\end{array}$ & $\begin{array}{c}0.615^{* * * *} * \\
(0.014)\end{array}$ & $\begin{array}{c}0.625^{* * * *} * \\
(0.01)\end{array}$ & $\begin{array}{c}0.602 * * * \\
(0.01)\end{array}$ & $\begin{array}{c}0.614 * * * \\
(0.01)\end{array}$ \\
\hline$h$ & $\begin{array}{c}0.115^{* * * *} * \\
(0.02)\end{array}$ & $\begin{array}{c}0.106 * * * \\
(0.02)\end{array}$ & $\begin{array}{c}0.122 * * * \\
(0.02)\end{array}$ & $\begin{array}{c}0.113 * * * \\
(0.02)\end{array}$ & $\begin{array}{c}0.122 * * * * \\
(0.02)\end{array}$ & $\begin{array}{c}0.114 * * * \\
(0.02)\end{array}$ & $\begin{array}{c}0.129 * * * \\
(0.02)\end{array}$ & $\begin{array}{c}0.122 * * * \\
(0.02)\end{array}$ \\
\hline$r$ & $\begin{array}{c}0.12 * * \\
(0.00)\end{array}$ & $\begin{array}{c}0.13^{* *} \\
(0.00)\end{array}$ & $\begin{array}{l}0.08^{*} \\
(0.00)\end{array}$ & $\begin{array}{c}0.10 * * \\
(0.00)\end{array}$ & $\begin{array}{c}0.04 * * \\
(0.00)\end{array}$ & $\begin{array}{c}0.04 * * \\
(0.00)\end{array}$ & $\begin{array}{l}0.06^{*} \\
(0.05)\end{array}$ & $\begin{array}{c}0.039 * \\
(0.00)\end{array}$ \\
\hline DSP & $\begin{array}{c}0.006 \\
(0.010)\end{array}$ & $\begin{array}{c}0.006 \\
(0.010)\end{array}$ & $\begin{array}{c}0.015 \\
(0.011)\end{array}$ & $\begin{array}{c}0.014 \\
(0.011)\end{array}$ & $\begin{array}{c}0.010 \\
(0.011)\end{array}$ & $\begin{array}{c}0.011 \\
(0.011)\end{array}$ & $\begin{array}{l}0.019 * \\
(0.012)\end{array}$ & $\begin{array}{c}0.019 \\
(0.012)\end{array}$ \\
\hline ISP1 & $\begin{array}{c}0.011^{* *} \\
(0.00)\end{array}$ & $\begin{array}{c}0.023^{* *} * \\
(0.01)\end{array}$ & & & & & & \\
\hline ISP2 & & & $\begin{array}{c}0.012 * * \\
(0.00)\end{array}$ & $\begin{array}{c}0.017 * * \\
(0.00)\end{array}$ & & & & \\
\hline ISP3 & & & & & $\begin{array}{c}0.010 * * \\
(0.00)\end{array}$ & $\begin{array}{c}0.037 * * * \\
(0.01)\end{array}$ & & \\
\hline ISP4 & & & & & & & $\begin{array}{c}0.012 * * \\
(0.00)\end{array}$ & $\begin{array}{c}0.024 * * \\
(0.01)\end{array}$ \\
\hline FDI & $\begin{array}{c}0.022 * * \\
(0.01)\end{array}$ & & $\begin{array}{c}0.018 * * \\
(0.00)\end{array}$ & & $\begin{array}{c}0.034 * * \\
(0.01)\end{array}$ & & $\begin{array}{c}0.024 * * \\
(0.01)\end{array}$ & \\
\hline VFDI & & $\begin{array}{l}0.005 \\
(0.00)\end{array}$ & & $\begin{array}{l}0.004 \\
(0.00)\end{array}$ & & $\begin{array}{l}0.007 \\
(0.00)\end{array}$ & & $\begin{array}{l}0.005 \\
(0.00)\end{array}$ \\
\hline$N$ & 1,556 & 1,556 & 1,508 & 1,508 & 1,556 & 1,556 & 1,508 & 1,508 \\
\hline Adj. $R^{2}$ & 0.9992 & 0.9992 & 0.9992 & 0.9992 & 0.9991 & 0.9991 & 0.9992 & 0.9992 \\
\hline$F$ & 23,388 & 17,102 & 21,386 & 16,022 & 15,798 & 14,152 & 16,897 & 14,215 \\
\hline Hansen test & 17.485 & 19.877 & 16.022 & 18.887 & 15.920 & 18.030 & 14.766 & 17.685 \\
\hline$p$ value & 0.231 & 0.134 & 0.312 & 0.169 & 0.318 & 0.205 & 0.394 & 0.222 \\
\hline LM test & 1163.232 & 1142.523 & 1540.039 & 1327.336 & 2100.853 & 1393.059 & 2029.860 & 1362.230 \\
\hline$p$ value & 0.00 & 0.00 & 0.00 & 0.00 & 0.00 & 0.00 & 0.00 & 0.00 \\
\hline
\end{tabular}

Notes: Clustered robust standard errors in parentheses with $* p<0.10, * * p<0.05$, *** $p<0.01$. The dependent variable $q$ is the $\log$ of gross output per hour worked. All specifications are estimated with the two step feasible GMM estimator. The instruments used are $k, m, h, r$, DSP, ISP, FDI, and VFDI in periods $(t-2)$ and $(t-3)$. Regressions include an intercept, country, industry, and time-fixed effects. The Hansen statistic of overidentification tests the hypothesis that the set of included instruments is valid, and thus the instruments are exogenous. The LM test is a likelihood ratio test of underidentification, testing the hypothesis that excluded instruments are relevant.

mechanisms; and restrictions). Figure 1 plots cross-country variability of this index over the period 1960-2010. A large standard deviation (SD) shows that data values are far away from the mean while a small SD means that data points are close to each other. Values very close to zero imply no deviation. Finland, Canada, and Australia present the highest variation in the sample with Spain, Denmark, and Japan to follow. With the exception of the United States whose SD is close to zero (0.1) - implying insignificant changes during 1960-2010-the Rights index has time variations even within a group of developed OECD countries. On the contrary, the score for the ease of doing business (World Bank 2007) has almost no time variation.

Our empirical strategy is to see how these two institutional factors interact with industry measures of HFDI and VFDI in stimulating productivity. To this end, we follow Coe,
FIGURE 1

Standard Deviation of Intellectual Property Rights Index (Rights), 1960-2010

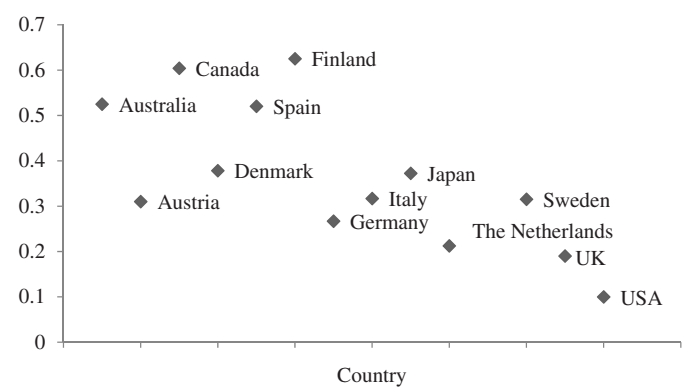

Helpman, and Hoffmaister (2009) and divide the sample of countries into groups of high, medium, and low, based on the relative ranking 
TABLE 9

Spillovers and Institutions-POLS Estimators-Equation (4)

\begin{tabular}{|c|c|c|c|c|c|}
\hline & 1 & 2 & 3 & 4 & 5 \\
\hline$k$ & $\begin{array}{c}0.518 * * * \\
(0.05)\end{array}$ & $\begin{array}{c}0.490 * * * \\
(0.05)\end{array}$ & $\begin{array}{c}0.168 * * * \\
(0.01)\end{array}$ & $\begin{array}{c}0.488 * * * \\
(0.05)\end{array}$ & $\begin{array}{c}0.586 * * * \\
(0.07)\end{array}$ \\
\hline$m$ & $\begin{array}{c}0.618 * * * \\
(0.00)\end{array}$ & $\begin{array}{c}0.632 * * * \\
(0.00)\end{array}$ & $\begin{array}{c}0.295 * * * \\
(0.01)\end{array}$ & $\begin{array}{c}0.630 * * * \\
(0.00)\end{array}$ & $\begin{array}{c}0.615 * * * \\
(0.01)\end{array}$ \\
\hline$h$ & $\begin{array}{c}0.104 * * * \\
(0.01)\end{array}$ & $\begin{array}{c}0.073 * * * \\
(0.01)\end{array}$ & $\begin{array}{c}0.054 * * * * \\
(0.01)\end{array}$ & $\begin{array}{c}0.068 * * * \\
(0.01)\end{array}$ & $\begin{array}{c}0.123 * * * \\
(0.02)\end{array}$ \\
\hline$r$ & $\begin{array}{c}0.00602 * * \\
(0.00)\end{array}$ & $\begin{array}{c}0.008 * * * \\
(0.00)\end{array}$ & $\begin{array}{c}0.007 * * * \\
(0.00)\end{array}$ & $\begin{array}{c}0.009 * * * \\
(0.00)\end{array}$ & $\begin{array}{l}0.007 \\
(0.00)\end{array}$ \\
\hline DSP & $\begin{array}{c}0.0354 * * * \\
(0.00)\end{array}$ & $\begin{array}{c}0.086 * * * \\
(0.00)\end{array}$ & $\begin{array}{c}0.048^{* * * *} \\
(0.01)\end{array}$ & $\begin{array}{c}0.088 * * * \\
(0.00)\end{array}$ & $\begin{array}{c}0.024 * * \\
(0.01)\end{array}$ \\
\hline ISP1 & $\begin{array}{c}0.0265 * * * \\
(0.00)\end{array}$ & $\begin{array}{c}0.067 * * * \\
(0.00)\end{array}$ & $\begin{array}{l}0.01^{*} \\
(0.00)\end{array}$ & $\begin{array}{c}0.070 * * * \\
(0.00)\end{array}$ & $\begin{array}{l}0.009 \\
(0.00)\end{array}$ \\
\hline FDI & $\begin{array}{c}0.0275^{* * *} * \\
(0.00)\end{array}$ & $\begin{array}{c}0.014 * * \\
(0.00)\end{array}$ & & $\begin{array}{c}0.037 * * * \\
(0.006)\end{array}$ & \\
\hline VFDI & & & $\begin{array}{c}0.093^{*} \\
(0.08)\end{array}$ & & $\begin{array}{c}0.159 * * \\
(0.07)\end{array}$ \\
\hline Rights & $\begin{array}{c}0.481 * * * \\
(0.02)\end{array}$ & & & & \\
\hline $\mathrm{Hi} \times \mathrm{HFDI}$ & & $\begin{array}{c}0.057 * * * \\
(0.01)\end{array}$ & & & \\
\hline Lo $\times$ HFDI & & $\begin{array}{c}-0.007 \\
(0.01)\end{array}$ & & & \\
\hline $\mathrm{Hi} \times \mathrm{VFDI}$ & & & $\begin{array}{c}0.091 * \\
(0.07)\end{array}$ & & \\
\hline Lo $\times$ VFDI & & & $\begin{array}{c}-6.322 * * * \\
(0.92)\end{array}$ & & \\
\hline $\mathrm{PP} \times \mathrm{Hi} \times \mathrm{HFDI}$ & & & & $\begin{array}{c}0.006^{* * * *} \\
(0.00)\end{array}$ & \\
\hline $\mathrm{PP} \times \mathrm{Lo} \times \mathrm{HFDI}$ & & & & $\begin{array}{c}-0.009 * * * \\
(0.00)\end{array}$ & \\
\hline $\mathrm{PP} \times \mathrm{Hi} \times \mathrm{VFDI}$ & & & & & $\begin{array}{c}0.035^{* *} * \\
(0.01)\end{array}$ \\
\hline $\mathrm{PP} \times \mathrm{Lo} \times \mathrm{VFDI}$ & & & & & $\begin{array}{c}-0.815^{* * * *} \\
(0.24)\end{array}$ \\
\hline$N$ & & 1,933 & 1,904 & 1,933 & 1,826 \\
\hline$R^{2}$ & & 0.998 & 0.733 & 0.998 & 0.999 \\
\hline$F$ & & 48833.61 & 191.14 & 48386.81 & 16374.16 \\
\hline$p$ value & & 0.000 & 0.000 & 0.000 & 0.000 \\
\hline
\end{tabular}

Notes: Standard errors in parentheses consistent for arbitrary heteroscedasticity with $* p<0.10, * * p<0.05, * * * p<0.01$. Regressions include an intercept, country, industry, and year-fixed effects.

of their score (Table A5 in Appendix D classifies countries of the sample, which gets reduced to the period $1987-2004^{19}$ based on the data on easiness of doing business). Then we define two dummy variables, high (Hi) and low (Lo) that are interacted with the FDI variables. A second hypothesis to be tested is whether simultaneously high degree of patent protection and relatively easy procedures in doing business can improve productivity from FDI-related spillovers. To save space, regressions in Table 9 include only ISP1 from import-related spillovers. ${ }^{20}$

19. Our production data cover up to 2007; so we could not make use of institutional data after that year.

20. Results from the remaining import-related indices are very similar and are available from the authors upon request.
Estimates in Table 9 are from a standard POLS with country, industry, and time dummies. CCEMG estimator is not applicable in this case as $h i$ and lo dummies are perfectly collinear with fixed effects. The autonomous coefficient of Rights in column (1) is positive and statistically significant. This implies that a highly protective system of intellectual property rights encourages investment in projects with high returns whose effects on productivity are crucial. Similar results are found with TFP measures by Coe, Helpman, and Hoffmaister (2009). The interaction terms of $\mathrm{Hi} \times \mathrm{HFDI}$ and Lo $\times$ HFDI in the first lower panel of Table 9 have opposite signs. These interaction coefficients should be interpreted relative to middle ranked countries as follows: countries 
with a relatively easier set of procedures in doing business can benefit more from FDI-related spillovers while countries with a relatively harder set of such procedures in doing business struggle to exploit FDI-related gains. This pattern remains the same for both HFDI and VFDI measures. The coefficients of triple interaction terms in the second lower panel of Table 9 suggest that high protection of patent rights in association with a relatively easier environment in doing business generates beneficial productivity effects. Similar results are obtained in the triple interaction with VFDI where the size of the estimated coefficient is relatively bigger than that of HFDI. Overall, Table 9 shows institutional heterogeneity whose impact on industry productivity varies substantially within OECD countries. This heterogeneity is more likely to be derived from variations in the ease of doing business given that most OECD countries have gradually adopted a highly protective system of property rights. The latter remark leaves great scope for policy design toward reforms that can simplify rules and procedures in the broader business environment. Our industry level results are in harmony with considerations and findings from country level studies on economic performance ${ }^{21}$ and institutions stressing the importance of a well-functioning institutional framework as a prerequisite for growth and prosperity.

\section{CONCLUSIONS}

The present study analyzes the impact of knowledge spillovers on output per worker using an approach directly derived from an augmented production function. The key objective of the study is to identify the importance of international spillovers under alternative assumptions regarding the information transferred through imports. This study also explores the importance of HFDI and VFDI in knowledge spillovers as well as how the institutional environment impacts on FDI-related spillovers. Through various specifications and robustness tests, the key findings of the article can be summarized as follows: international knowledge spillovers are an important driver of industry output per worker; the economic size of this effect is smaller the more restrictive the assumptions are about the amount of information embodied in imports; the elasticity of output with respect to spillovers is not negligible but it is definitely lower than industry's own R\&D; the effect of spillovers on productivity is mainly driven by high technology industries as SUR estimates have shown; and low tech industries are weak in absorbing knowledge spillovers. The study has not revealed substantial gains from intraindustry domestic spillovers. HFDI is an important vehicle for productivity improvements. The gains from HFDI increase with the degree of protection of intellectual property rights in the recipient country and the degree of easiness of doing business. These institutional factors are also crucial conditions for the implementation of VFDI-related spillovers.

Overall our results indicate that international knowledge spillovers exist and imports together with FDI are crucial vehicles for diffusion of foreign knowledge. Present findings are robust to econometric estimations that account for crosssectional and endogeneity bias, unlike in the traditional literature. Nonetheless, there are some constant caveats that apply when one seeks to provide interpretation of the present findings. First, we need more direct technology indicators associated with respect to FDI in order to provide more direct links between knowledge diffusion and productivity. Data on patent citations and licences can be more informative on how domestic firms benefit from foreign know-how. Second, an issue that still remains underinvestigated is to disentangle FDI knowledge spillovers from FDI competition enhancing effects. These issues need to be taken up in future research.

A policy message is also clear from the present study: trade and multinational activities by firms can improve productivity at the industry level but these gains are bigger if there is an appropriate institutional environment. Given that the evidence in this study is drawn from high-income OECD countries where protection of intellectual property rights is already strong, the policy focus must be on simplifying the procedures for doing business. Policy reforms along this direction can yield substantial FDI-related gains. 


\section{APPENDIX A. Descriptive Evidence}

\section{FIGURE A1}

Output per Worker in Representative Industries for OECD-14-1987-2007

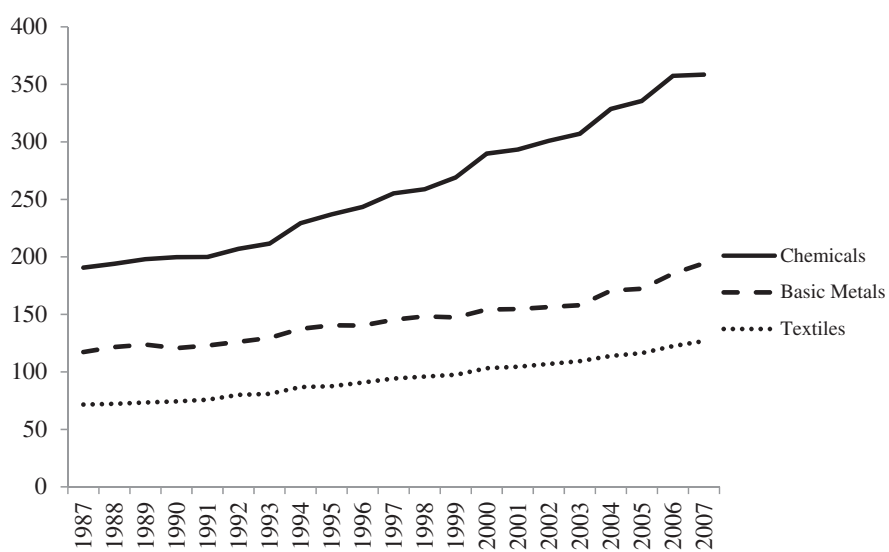

Note: Output per worker is gross output per hour worked in thousands of 2000 PPP-USD.

FIGURE A2

Manufacturing Output per Worker in Denmark, Germany, and USA, 1987-2007

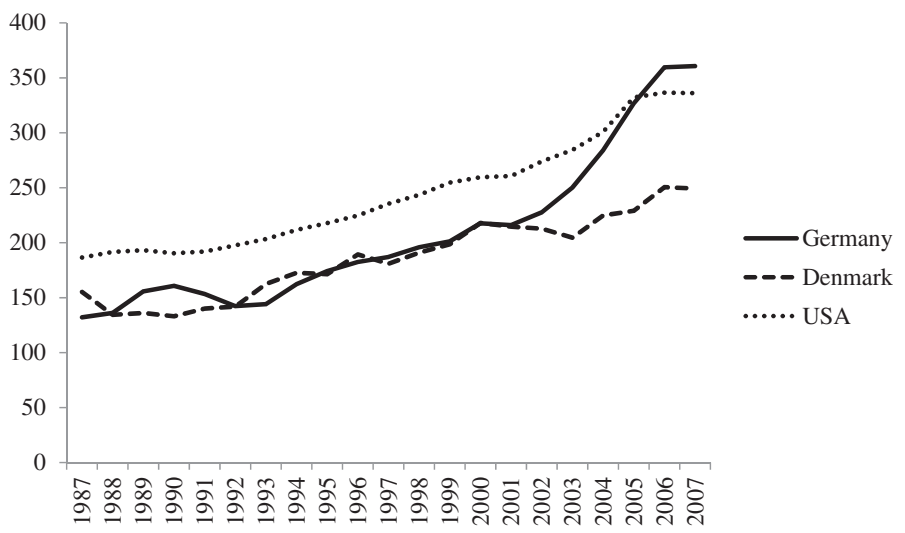

TABLE A1

Summary Statistics

\begin{tabular}{lccrr}
\hline Variable & Mean & SD & Min & Max \\
\hline$q$ & 5.06 & 0.65 & 2.46 & 8.53 \\
$k$ & 0.58 & 0.44 & -0.71 & 3.34 \\
$m$ & 3.19 & 0.90 & 1.35 & 8.24 \\
$h$ & 4.04 & 9.38 & -47.65 & 77.21 \\
$r$ & 0.65 & 1.11 & -3.94 & 1.92 \\
DSP & 6.04 & 2.46 & -2.13 & 12.21 \\
ISP1 & 22.99 & 1.93 & 14.77 & 28.26 \\
ISP2 & 22.91 & 2.42 & 13.79 & 6.34 \\
ISP3 & 2.75 & 1.66 & -3.68 & 6.44 \\
ISP4 & 2.59 & 2.15 & -4.66 & 6.78 \\
HFDI & 5.84 & 1.88 & 0.80 & 11.34 \\
VFDI & 0.25 & 1.26 & 0.00 & 20.53 \\
Rights & 3.55 & 0.93 & 1.84 & 4.88 \\
\hline
\end{tabular}


TABLE A2

Correlation Matrix of Knowledge Spillover Indices

\begin{tabular}{lcccc}
\hline & ISP1 & ISP2 & ISP3 & ISP4 \\
\hline ISP1 & 1.00 & & & \\
ISP2 & 0.92 & 1.00 & 1.00 & 1.00 \\
ISP3 & 0.56 & 0.56 & 0.89 & 0.73 \\
ISP4 & 0.56 & & & \\
\hline
\end{tabular}

APPENDIX B. Baseline POLS Results

TABLE A3

Baseline POLS Results from Equation (4)

\begin{tabular}{|c|c|c|c|c|}
\hline & 1 & 2 & 3 & 4 \\
\hline$k$ & $\begin{array}{c}0.609 * * * \\
(0.02)\end{array}$ & $\begin{array}{c}0.611 * * * \\
(0.02)\end{array}$ & $\begin{array}{c}0.611 * * * \\
(0.02)\end{array}$ & $\begin{array}{c}0.612 * * * \\
(0.02)\end{array}$ \\
\hline$m$ & $\begin{array}{c}0.620 * * * \\
(0.01)\end{array}$ & $\begin{array}{c}0.619 * * * \\
(0.01)\end{array}$ & $\begin{array}{c}0.622 * * * \\
(0.01)\end{array}$ & $\begin{array}{c}0.622 * * * \\
(0.01)\end{array}$ \\
\hline$h$ & $\begin{array}{c}0.151 * * * \\
(0.01)\end{array}$ & $\begin{array}{c}0.153^{* * * *} \\
(0.01)\end{array}$ & $\begin{array}{c}0.160 * * * \\
(0.01)\end{array}$ & $\begin{array}{c}0.159 * * * \\
(0.01)\end{array}$ \\
\hline$r$ & $\begin{array}{c}0.22 * * \\
(0.00)\end{array}$ & $\begin{array}{c}0.31 * * * \\
(0.00)\end{array}$ & $\begin{array}{l}0.12^{*} \\
(0.00)\end{array}$ & $\begin{array}{l}0.08^{*} \\
(0.00)\end{array}$ \\
\hline DSP & $\begin{array}{l}0.001 \\
(0.00)\end{array}$ & $\begin{array}{l}0.002 \\
(0.00)\end{array}$ & $\begin{array}{c}-0.001 \\
(0.00)\end{array}$ & $\begin{array}{l}0.000 \\
(0.00)\end{array}$ \\
\hline ISP1 & $\begin{array}{c}0.008 * * * \\
(0.00)\end{array}$ & & & \\
\hline ISP2 & & $\begin{array}{c}0.006^{* * * *} \\
(0.00)\end{array}$ & & \\
\hline ISP3 & & & $\begin{array}{l}0.003 \\
(0.00)\end{array}$ & \\
\hline ISP4 & & & & $\begin{array}{l}0.003 \\
(0.00)\end{array}$ \\
\hline$N$ & 2,753 & 2,753 & 2,753 & 2,753 \\
\hline$R^{2}$ & 0.926 & 0.926 & 0.926 & 0.926 \\
\hline$F / p$ value & $824.97 / 0.00$ & $\begin{array}{c}797.87 \\
0.000\end{array}$ & $\begin{array}{c}781.77 \\
0.000\end{array}$ & $\begin{array}{c}783.46 \\
0.000\end{array}$ \\
\hline $\mathrm{AB}(1) / p$ value & $4.55 / 0.00$ & $4.61 / 0.00$ & $2.30 / 0.02$ & $2.33 / 0.02$ \\
\hline $\mathrm{AB}(2) / p$ value & $1.10 / 0.27$ & $1.12 / 0.23$ & $1.07 / 0.28$ & $1.09 / 0.27$ \\
\hline $\mathrm{AB}(3) / p$ value & $0.41 / 0.67$ & $0.43 / 0.67$ & $0.37 / 0.71$ & $0.38 / 0.70$ \\
\hline
\end{tabular}

Notes: Standard errors in parentheses consistent for arbitrary heteroscedasticity with $* p<0.10, * * p<0.05, * * * p<0.01$. The dependent variable $q$ is the log of gross output per hour worked. All regressions include an intercept, country, industry, and year-fixed effects. AB refers to Arellano and Bond (1991) test for serial correlation and reported up to three lags.

The Common Correlated Effects estimator of Pesaran (2006) is written as:

$$
\begin{aligned}
y_{i t} & =\alpha_{0}+\mathbf{b}^{\prime} \mathbf{X}_{i t}+\sum_{j=2}^{N} d_{j} D_{j}+\sum_{t=2}^{T} \sum_{j=1}^{N} \Psi_{1}\left(\bar{y}_{t} D_{j}\right) \\
& +\sum_{k=1}^{m} \sum_{t=2}^{T} \sum_{j=1}^{N} \boldsymbol{\Psi}_{2 i}\left(\overline{\mathbf{X}}_{\mathbf{t}} D_{j}\right)+u_{i t} .
\end{aligned}
$$

The first three terms represent a standard-fixed effects estimator. Terms 4 and 5 in the summations are interaction terms between cross-section averages and $N$ cross-section specific dummies. This estimator is the Common Correlated Effects Pooled estimator. The CCEMG used in the article can be seen if interaction terms in the second and third summation are replaced by cross-section averages of $y$ and $\mathbf{X}$. 
APPENDIX C. Industry Specific Estimates

TABLE A4

Industry Regressions from CCEMG

\begin{tabular}{lcccrrr}
\hline & $\boldsymbol{k}$ & $\boldsymbol{m}$ & $\boldsymbol{h}$ & $\boldsymbol{r}$ & DSP & ISP1 \\
\hline Food & 0.639 & 0.370 & 0.011 & 0.269 & -0.097 & 0.012 \\
Textiles & 0.609 & 0.446 & 0.046 & 0.192 & -0.675 & 0.058 \\
Printing & 0.207 & 0.413 & 0.090 & 0.316 & -0.496 & 0.040 \\
Coke & 0.169 & 0.227 & 0.113 & 0.450 & 0.002 & -0.028 \\
Chemicals & 0.407 & 0.506 & 0.060 & 0.17 & 0.593 & 0.124 \\
Rub \& Pl. & 0.368 & 0.353 & -0.030 & 0.345 & 0.000 & 0.118 \\
Nonmetallic miner. & 0.311 & 0.487 & -0.003 & 0.230 & 0.376 & -0.101 \\
Basic metals & 0.361 & 0.349 & 0.276 & 0.336 & 0.652 & 0.169 \\
Machinery & 0.313 & 0.341 & -0.006 & -0.115 & 0.419 & -0.149 \\
Elec. equipment & 0.681 & 0.446 & -0.333 & -0.157 & -0.326 & 0.094 \\
Transport equip. & 0.585 & 0.522 & 0.197 & 0.135 & -0.375 & -0.096 \\
Other manufacturing & 0.145 & 0.444 & -0.023 & 0.256 & 0.001 & -0.101
\end{tabular}

Notes: CCMEG allows for cross-section parameter heterogeneity both in the observables and the unobservables. The results shown in Table 4 refer to cross-industry averages reported in this table.

APPENDIX D. Intellectual Property Rights and Business Environment

TABLE A5

Institutional Factors

\begin{tabular}{llll}
\hline & \multicolumn{2}{c}{ Intellectual Property Rights Index $($ Rights $)$} & \\
\cline { 2 - 3 } Country & $\mathbf{1 9 8 7}$ & $\mathbf{2 0 0 4}$ & Ease of Doing Business \\
\hline Australia & 2.962 & 4.167 & High \\
Austria & 3.583 & 4.333 & Low \\
Canada & 3.233 & 4.667 & High \\
Denmark & 3.783 & 4.667 & High \\
Spain & 3.258 & 4.333 & Low \\
Finland & 3.308 & 4.642 & Medium \\
Germany & 3.917 & 4.500 & Medium \\
Italy & 3.878 & 4.667 & Low \\
Japan & 3.700 & 4.667 & Medium \\
Netherlands & 4.037 & 4.667 & Medium \\
Sweden & 3.723 & 4.542 & Medium \\
UK & 4.158 & 4.542 & High \\
USA & 4.675 & 4.875 & High \\
Mean & 3.793 & 4.559 & \\
\hline
\end{tabular}

\section{REFERENCES}

Acemoglu, D., S. Johnson, and J. A. Robinson. "Institutions as a Fundamental Cause of Long-run Growth," in Handbook of Economic Growth, Vol. 1, edited by P. Aghion and S. N. Durlauf. Amsterdam, The Netherlands: Elsevier, 2005, 385-472.

Acharya, R. C., and W. Keller. "Technology Transfer through Imports." Canadian Journal of Economics, 42(4), 2009, 1411-48.

Aghion, P., and P. Howitt. "Endogenous Growth Theory." Economic Growth, 2, 1998, 71-102.

Aghion, P., P. Howitt, and S. Prantl. "Patent Rights, Product Market Reforms, and Innovation." Journal of Economic Growth, 20(3), 2015, 223-62.

Aitken, B. J., and A. E. Harrison. "Do Domestic Firms Benefit from Direct Foreign Investment? Evidence from Venezuela." American Economic Review, 89, 1999, 605-18.
Anderson, T. W. 1984. An Introduction to Multivariate Statistical Analysis. 2nd ed. New York: John Wiley \& Sons.

Ang, J. B., and J. B. Madsen. "International R\&D Spillovers and Productivity Trends in the Asian Miracle Economies.” Economic Inquiry, 51(2), 2013, $1523-41$.

Arellano, M., and S. Bond. "Some Tests of Specification for Panel Data: Monte Carlo Evidence and an Application to Employment Equations." Review of Economic Studies, 58(2), 1991, 277-97.

Augier, P., O. Cadot, and M. Dovis. "Imports and TFP at the Firm Level: The Role of Absorptive Capacity." Canadian Journal of Economics/Revue canadienne d'économique, 46(3), 2013, 956-81.

Bartelsman, E. J. "Federally Sponsored R\&D and Productivity Growth," Finance and Economics Discussion Series 121, Board of Governors of the Federal Reserve System (U.S.), 1990. 
Benhabib, J., and M. M. Spiegel. "The Role of Human Capital in Economic Development Evidence from Aggregate Cross-Country Data." Journal of Monetary Economics, 34(2), 1994, 143-73.

Bernstein, J. I., and X. Yan. "International R\&D Spillovers between Canadian and Japanese Industries." Canadian Journal of Economics, 30(2), 1997, 276-94.

Bitzer, J., and M. Kerekes. "Does Foreign Direct Investment Transfer Technology Across Borders? New Evidence." Economics Letters, 100(3), 2008, 355-58.

Blalock, G., and P. J. Gertler. "Welfare Gains from Foreign Direct Investment through Technology Transfer to Local Suppliers." Journal of International Economics, 74(2), 2008, 402-21.

Branstetter, L. G. "Are Knowledge Spillovers International or Intranational in Scope? Microeconometric Evidence from the US and Japan." Journal of International Economics, 53(1), 2001, 53-79.

- "Is Foreign Direct Investment a Channel of Knowledge Spillovers? Evidence from Japan's FDI in the United States." Journal of International Economics, 68(2), 2006, 325-44

Breusch, T. S., and A. R. Pagan. "A Simple Test for Heteroscedasticity and Random Coefficient Variation." Econometrica: Journal of the Econometric Society, 47, 1979, 1287-94.

Cameron, G., J. Proudman, and S. Redding. "Technological Convergence, R\&D, Trade and Productivity Growth." European Economic Review, 49(3), 2005, 775-807.

Carr, D. L., J. R. Markusen, and K. E. Maskus. "Estimating the Knowledge-Capital Model of the Multinational Enterprise." American Economic Review, 91(3), 2001, 693.

Coakley, J., A.-M. Fuertes, and R. Smith. "Unobserved Heterogeneity in Panel Time Series Models." Computational Statistics \& Data Analysis, 50(9), 2006, 2361-80.

Coe, D. T., and E. Helpman. "International R\&D Spillovers." European Economic Review, 39(5), 1995, 859-87.

Coe, D. T., E. Helpman, and A. W. Hoffmaister. "North-South R \& D Spillovers." The Economic Journal, 107(440), 1997, 134-49.

. "International R\&D Spillovers and Institutions." European Economic Review, 53(7), 2009, 723-41.

Corrado, C. A., and C. R. Hulten. "How Do You Measure a Technological Revolution?" American Economic Review, 100(2), 2010, 99-104.

Dougherty, C., and D. W. Jorgenson. "International Comparisons of the Sources of Economic Growth." American Economic Review, 86, 1996, 25-29.

Eberhardt, M., C. Helmers, and H. Strauss. "Do Spillovers Matter When Estimating Private Returns to R\&D?" Review of Economics and Statistics, 95(2), 2013, 436-48.

Engelbrecht, H.-J. "International R\&D Spillovers, Human Capital and Productivity in OECD Economies: An Empirical Investigation." European Economic Review, 41(8), 1997, 1479-88

Falvey, R., N. Foster, and D. Greenaway. "Imports, Exports, Knowledge Spillovers and Growth." Economics Letters, 85(2), 2004, 209-13.

Fosfuri, A., M. Motta, and T. Rønde. "Foreign Direct Investment and Spillovers through Workers'Mobility." Journal of International Economics, 53(1), 2001, 205-22.

Funk, M. "Trade and International R\&D Spillovers among OECD Countries." Southern Economic Journal, 67, 2001, 725-36.

Good, D. H., M. I. Nadiri, and R. C. Sickles. "Index Number and Factor Demand Approaches to the Estimation of Productivity." National Bureau of Economic Research Working Paper No. 5790, 1996.
Griffith, R., S. Redding, and J. Van Reenen. "Mapping the Two Faces of R\&D: Productivity Growth in a Panel of OECD Industries." Review of Economics and Statistics, 86(4), 2004, 883-95.

Griliches, Z. "Issues in Assessing the Contribution of Research and Development to Productivity Growth." Bell Journal of Economics, 10(1), 1979, 92-116.

-. "R \& D and the Productivity Slowdown." American Economic Review, 70, 1980, 343-48.

Griliches, Z., and J. Mairesse. "Productivity and R\&D at the Firm Level," in $R \& D$, Patents, and Productivity, edited by Z. Griliches. Chicago: University of Chicago Press, 1984, 339-74.

Grossman, G., and E. Helpman. Innovation and Growth in the World Economy. Cambridge, MA: MIT Press, 1991.

Hall, B. H., and J. Mairesse. "Exploring the Relationship between R\&D and Productivity in French Manufacturing Firms." Journal of Econometrics, 65(1), 1995, 263-93.

Hall, B. H., J. Mairesse, and P. Mohnen. "Measuring the Returns to R\&D," in Handbook of the Economics of Innovation, Vol. 2, edited by B. H. Hall and N. Rosenberg. Amsterdam, The Netherlands: Elsevier, 2010, $1033-82$.

Hansen, L. P. "Large Sample Properties of Generalized Method of Moments Estimators." Econometrica: Journal of the Econometric Society, 50, 1982, 1029-54.

Harrigan, J. "Technology, Factor Supplies, and International Specialization: Estimating the Neoclassical Model." American Economic Review, 87, 1997, 475-94.

Haskel, J. E., S. C. Pereira, and M. J. Slaughter. "Does Inward Foreign Direct Investment Boost the Productivity of Domestic Firms?" Review of Economics and Statistics, 89(3), 2007, 482-96.

Havranek, T., and Z. Irsova. "Estimating Vertical Spillovers from FDI: Why Results Vary and What the True Effect Is." Journal of International Economics, 85(2), 2011, 234-44.

Higón, D. A. "The Impact of R\&D Spillovers on UK Manufacturing TFP: A Dynamic Panel Approach.” Research Policy, 36(7), 2007, 964-79.

Islam, N. "Growth Empirics: A Panel Data Approach." Quarterly Journal of Economics, 110(4), 1995, 1127-70.

Javorcik, B. S. "Does Foreign Direct Investment Increase the Productivity of Domestic Firms? In Search of Spillovers through Backward Linkages." American Economic Review, 94(3), 2004, 605-27.

. "Can Survey Evidence Shed Light on Spillovers from Foreign Direct Investment?" The World Bank Research Observer, 23(2), 2008, 139-59.

Javorcik, B. S., and M. Spatareanu. "To Share or Not to Share: Does Local Participation Matter for Spillovers from Foreign Direct Investment?" Journal of Development Economics, 85(1), 2008, 194-217.

Kao, C., M.-H. Chiang, and B. Chen. "International R\&D Spillovers: An Application of Estimation and Inference in Panel Cointegration." Oxford Bulletin of Economics and Statistics, 61(S1), 1999, 691-709.

Kapetanios, G., M. H. Pesaran, and T. Yamagata. "Panels with Non-stationary Multifactor Error Structures." Journal of Econometrics, 160(2), 2011, 326-48.

Keller, W. "Are International R\&D Spillovers Trade-Related? Analyzing Spillovers Among Randomly Matched Trade Partners." European Economic Review, 42(8), 1998, $1469-81$.

- "Geographic Localization of International Technology Diffusion." American Economic Review, 92(1), 2002, 120-42.

. "International Technology Diffusion." Journal of Economic Literature, 42, 2004, 752-82. 
"International Trade, Foreign Direct Investment, and Technology Spillovers," in Handbook of the Economics of Innovation, Vol. 2, edited by B. H. Hall and N. Rosenberg. Amsterdam, The Netherlands: Elsevier, 2010, 793-829.

Keller, W., and S. R. Yeaple. "Multinational Enterprises, International Trade, and Productivity Growth: FirmLevel Evidence from the United States." Review of Economics and Statistics, 91(4), 2009, 821-31.

Klump, R., P. McAdam, and A. Willman. "Unwrapping Some Euro Area Growth Puzzles: Factor Substitution, Productivity and Unemployment." Journal of Macroeconomics, 30(2), 2008, 645-66.

-. "The Normalized CES Production Function: Theory and Empirics." Journal of Economic Surveys, 26(5), 2012, 769-99.

León-Ledesma, M. A. "Exports, Product Differentiation and Knowledge Spillovers." Open Economies Review, 16(4), 2005, 363-79.

Mancusi, M. L. "International Spillovers and Absorptive Capacity: A Cross-country Cross-sector Analysis Based on Patents and Citations." Journal of International Economics, 76(2), 2008, 155-65.

Meijl, H. V. "Measuring Intersectoral Spillovers: French Evidence." Economic Systems Research, 9(1), 1997, $25-46$.

McAdam, P., and A. Willman. "Medium Run Redux." Macroeconomic Dynamics, 17(04), 2013, 695-727.

Miller, S. M., and M. P. Upadhyay. "The Effects of Openness, Trade Orientation, and Human Capital on Total Factor Productivity." Journal of Development Economics, 63(2), 2000, 399-423.

Nickell, S., S. Redding, and J. Swaffield. "The Uneven Pace of Deindustrialisation in the OECD." The World Economy, 31(9), 2008, 1154-84.

Ortega-Argilés, R., M. Vivarelli, and P. Voigt. "R\&D in SMEs: A Paradox?" Small Business Economics, 33(1), 2009, 3-11.

Park, J. "International and Intersectoral R\&D Spillovers in the OECD and East Asian Economies." Economic Inquiry, 42(4), 2004, 739-57.

Park, W. G., and D. Lippoldt. "International Licensing and the Strengthening of Intellectual Property Rights in Developing Countries during the 1990s." OECD Economic Studies, 40(1), 2005, 7-48.

Pedroni, P. "Social Capital, Barriers to Production and Capital Shares: Implications for the Importance of Parameter
Heterogeneity from a Nonstationary Panel Approach." Journal of Applied Econometrics, 22(2), 2007, 429-51.

Pesaran, M. H. "General Diagnostic Tests for Cross Section Dependence in Panels." IZA Discussion Paper No. 1240, 2004

. "Estimation and Inference in Large Heterogeneous Panels with a Multifactor Error Structure." Econometrica, 74(4), 2006, 967-1012.

Rogers, M. "R\&D and Productivity: Using UK FirmLevel Data to Inform Policy." Empirica, 37(3), 2010, 329-59.

Romer, P. M. "Increasing Returns and Long-Run Growth." Journal of Political Economy, 94, 1986, 1002-37.

Schiff, M., and Y. Wang. "North-South and South-South Trade-Related Technology Diffusion: An IndustryLevel Analysis of Direct and Indirect Effects." Canadian Journal of Economics, 39(3), 2006, 831-44.

Schneider, P. H. "International Trade, Economic Growth and Intellectual Property Rights: A Panel Data Study of Developed and Developing Countries." Journal of Development Economics, 78(2), 2005, 529-47.

Syverson, C. "What Determines Productivity?" Journal of Economic Literature, 49(2), 2011, 326-65.

Timmer, M. P., M. O'Mahony, and B. Van Ark. "Growth and Productivity Accounts from EU KLEMS: An Overview." National Institute Economic Review, 200(1), 2007, 64-78.

Van Ark, B., D. Pilat, D. Jorgenson, and F. R. Lichtenberg. "Productivity Levels in Germany, Japan, and the United States: Differences and Causes." Brookings Papers on Economic Activity: Microeconomics, 1993(2), 1993, $1-69$.

Van Pottelsberghe, B., and F. Lichtenberg. "Does Foreign Direct Investment Transfer Technology across Borders?" Review of Economics and Statistics, 83(3), 2001, 490-97.

Wolff, E. N., and M. I. Nadiri. "Spillover Effects, Linkage Structure, and Research and Development." Structural Change and Economic Dynamics, 4(2), 1993, 315-31.

World Bank. "Doing Business 2008." Washington, DC: World Bank, 2007.

$\mathrm{Xu}, \mathrm{B}$. . "Multinational Enterprises, Technology Diffusion, and Host Country Productivity Growth." Journal of Development Economics, 62(2), 2000, 477-93.

Yasar, M.. "Imported Capital Input, Absorptive Capacity, and Firm Performance: Evidence from Firm-Level Data." Economic Inquiry, 51(1), 2013, 88-100. 